\title{
Book Four: The Royal Dynasties
}

\section{The Solar Dynasty: The lineage of Manu}

\section{Maitreya:}

Master, as my guru, you've told me what regular and occasional rites must be performed by those committed to good conduct. 1

You've also described the duties of the four communities and life stages. Now I'd like to hear about the historical lineages, guru. Please tell me all about them. 2

\section{Parāśara:}

Maitreya, you'll now hear about the lineage of Manu, which begins with Brahmā, and which boasts many sacrificers, heroes, warriors and kings. 3 As the saying goes, 'The lineage of one who reflects each day on Manu's family, which descends from Brahmā, is never broken.' \& You should therefore listen to this lineage from start to finish, Maitreya, as it will wash away all sins. 5

It is as follows: in the beginning, Lord Brahmā, Hiranyagarbha, appeared from the cosmic egg, the incarnate form of the Absolute, which consists of Lord Visnu, beginningless in all the worlds, the primeval cause, embodying the Rg, Yajur and Säma Vedas. 6 The patriarch Dakṣa arose from Brahmā's right thumb. Dakșa's daughter was Aditi. Aditi's son was the Sun. The son of the Sun was Manu. 7 Manu had ten sons, named Ikṣvāku, Nṛa, Dhṛșta, Śaryāti, Narișyanta, Prāṃśu, Nābhāga, Nedișța, Karūṣa and Pṛ̣adhra. 8

Desiring yet another son, Manu performed a sacrifice to Mitra and Varuna. 9 Because the invocatory priest erred during that corrupted rite, a daughter by the name of Ilā was born. 10 By the grace of the two deities, Maitreya, she was transformed into a son for Manu, named Sudyumna. 11 Later, as a result of Śiva's anger, Sudyumna became a woman once more, 
and wandered into the vicinity of the ashram of Budha, son of the Moon. 12 Budha fell in love with her and they had a son, Purūravas. 13 After the baby was born, the great sages of immeasurable energy, desiring to turn Sudyumna back into a man, performed a sacrifice for Lord Viṣnu, who embodies the Rg, Yajur, Säma and Atharva Vedas, mind and knowledge, everything and nothingness, and who takes the form of the spirit of the sacrifice. Through the mercy of the deity, Ila became Sudyumna once more. 14 He had three sons, named Utkala, Gaya and Vinata. 15 Because he'd previously been a woman, Sudyumna received no share of his father's kingdom. 16 His father, however, at the suggestion of Vasiștha, gave him the city named Pratișțhāna, which he later bestowed on Purūravas. 17

Manu's son Pṛșadhra was reduced to the status of a śüdra because he killed his guru's cow. 18 From Karūṣa were descended the kṣatriyas known as Kārūṣas, possessed of peerless strength and courage. 19 Nedișta's son Nābhāga became a vaiśya and had a son, Bhalandana. ${ }^{1} 20$ Bhalandana's son was the renowned Vatsapri. 21 Vatsupri's son was Prāṃśu. 22 Prāṃśu's only son was Prajāni. 23 His son was Khanitra, and his son was Cakșupa. From Cakṣupa was descended Viṃśa, mighty and courageous. 24 His son was Vivimiśa, and his son was Khaninetra. His son was Ativibhūti. 25 Ativibhūti's son was Karandhama, who was even stronger and more courageous than his father. His son was Avikṣi. Avikși's mighty son was Marutta, about whom these two verses are sung today: 26

'Who in this world has held a sacrifice like Marutta's, in which all utensils were made of shining gold? 27

Indra got drunk on soma and the brahmins got drunk on their fees. The Maruts served the food, and all the gods were there.' 28

The universal monarch Marutta had a son named Narisyanta. 29 His son was Dama, and Dama had a son, Rājyavardhana. 30 Rājyavardhana's son was Sudhrti. His son was Nara, and his son was Kevala. Kevala's son was Bandhumant. Bandhumant's son was Vegavant. Vegavant's son was Budha. His son was Tṛnabindu. 31 He had one daughter, Ilavilā by name. 32 An excellent apsaras named Alambușā fell in love with Tṛnabindu, 33 and they had a son, Viśāla, who founded the city known as Vaiśāī. 34 Viśāla's son was Hemacandra. 35 His son was Sucandra. His son was Dhūmrāśva, and his son was Srñnjaya. 36 Sṛñjaya's son was Sahadeva. He had a son called

1 At 4.1.8, Nābhāga and Nedișța are said to be brothers. 
Kṛsāśva. 37 Kṛsaasśva’s son Somadatta performed ten horse-sacrifices. 38 His son was Janamejaya. Janamejaya's son was Sumati. These were the kings of Vaiśâlī, 39 about whom this verse is sung:

'By the grace of Tṛnabindu, all the kings of Vaiśâlī were long-lived, generous, brave and good.' 40

Manu's son Śaryāti had a daughter by the name of Sukanyā, whom Cyavana married. ${ }_{41}$ Śaryāti had a virtuous son called Ānarta. 42 Ānarta's son, Revata, ruled a kingdom named after his father and resided in the city of Kuśasthalī. 43

\section{Brahmā suggests that Revatī marry Balarāma}

Revata's son was Raivata, also known as Kakudmin. He was the eldest of one hundred brothers and was a man of virtue. 44 Raivata had a daughter named Revati. Raivata took his daughter with him to the realm of Brahmā, in order to ask the lotus-born deity for a husband worthy of the girl. 45 Just as he arrived, two gandharvas, Hāhā and Hūhū by name, were singing a heavenly song called 'Atitāna' in the presence of the deity. 46 Even though Raivata waited for many entire cycles of ages, it seemed that he'd only been listening for a moment. 47 At the end of the song, Raivata bowed to Brahmā, the lotus-born deity, and asked about a suitable husband for his daughter. 48

The lord replied, 'Tell me, who would you like to marry her?' 49 Raivata bowed again to the lord and mentioned the names of potential husbands of whom he approved, adding, 'I'll give my daughter to whichever of these the lord thinks suitable.' so The lotus-born deity gave a little nod and said with a smile, 51 'Even the great-grandchildren of those you think fit are no longer living. 52 Many cycles of ages passed while you listened to that song. 53 At this moment, the twenty-eighth cycle of the present Manu is nearly over, and the age of Kali is about to begin on earth. 54 Give this gem of a girl to someone else. You're now on your own, 55 as your friends, ministers, servants, wives, kinsfolk, armies and treasuries have all been swept away by the passage of time.' 56 The astonished king bowed to Brahmā again and asked, 57 'In that case, Lord, to whom should I give her?' 58 The holy lotusborn preceptor of all the worlds then replied to the king, whose head was slightly bowed and whose hands were joined in supplication: 59

'The unborn universal arranger, the supreme lord whose beginning, middle, end, form, highest state and essence are unknown to us, 60 
Is beyond time, which, composed of minutes, hours and other units, brings an end to all creation. He is free from birth and death, embodies everything, has neither name nor form, and is eternal. 61

By the grace of that imperishable being, I became the creator of the world and, through his anger, Rudra brings it to an end. In the interim, purusa, the Spirit, arises from him to preserve it. 62

The unborn deity takes my form to create the world, maintains it in the form of Spirit and consumes all this in Rudra's form. That divine being, whose forms are endless, disposes everything. 63

In the form of mighty Indra and the gods, he guards the world; in the form of sun and moon, he dispels the gloom. He takes the form of fire to bring us warmth; in the form of earth, he supports the world, yet his essence is unchanging. 64

In the form of breath, he enables all activity; in the form of food and water, he nourishes the world. He occupies all creation and, in the form of ether, provides the space wherein all things abide. 65

He is both creation and creator, the object of protection and the deity who protects it, destroyer and destroyed, but as the changeless universal being he remains distinct from these. 66

The world abides in him, he is the world, the primary being, the self-arising one abiding in all things, yet is superior to all creation. Now, your majesty, Viṣnu has manifested an aspect of himself on earth. 67

The city of Kuśasthalī, as lovely as Indra’s Amarāvatī and previously your majesty's capital, is now known as Dvārakā. There resides one Balarāma by name, an aspect of Lord Keśava. ${ }^{2} 68$

Give this girl to him in marriage, your majesty. He is divine illusion in human form, and is a husband worthy of the girl, a fitting partner for that gem of womanhood.' 69

\section{Parāśara:}

Thus addressed by lotus-born Brahmā, the king returned to earth, where he noticed all the people were now shorter and less vigorous, discerning and courageous than they were before. 70

2 The text actually gives the name of Kṛṣna's elder brother as Baladeva at this point. For clarity, I have standardised on Balarāma throughout, as mentioned in the Introduction. 
On reaching the city of Kuśasthalī, which now looked somewhat different, the wise king gave his daughter to Balarāma, whose weapon was a plough and whose broad chest gleamed like a crystal mountain. 71

Balarāma, who bore a palm tree on his standard, saw the princess and, considering her unnecessarily tall, pressed her down with his ploughshare. She was reduced at once to the height of other women. 72

That plough-wielding warrior duly married King Raivata's daughter, Revatī. After giving the girl away, Raivata retired to the Himālaya to undertake austerities. 73

So ends Chapter One in Book Four of the glorious Viṣnu Purāna.

\section{Manu’s sons Dhṛsta, Nābhāga and Ikṣvāku}

\section{Parāśara:}

Before Kukudmin Raivata returned from Brahmā's realm, rākṣasas known as Punyajanas attacked his capital, Kuśasthalī. 1 His one hundred brothers, fearing the Punyajanas, fled in all directions. 2 As a result, kșatriya lineages sprang up everywhere. 3 From Manu's son Dhṛsța arose the warrior lineage of Dhārșțakas. 4 Nābhāga's son was Nabhaga. ${ }^{3}$ His son was Ambarịsa. Ambarīṣa’s son was Virūpa. 5 Virūpa's son was Pṛ̣adaśva. After him came Rathitara. 6 There is a verse about these kings:

'Born as kṣatriyas, they're known as Angirases, Angiras's offspring. The families of Rathītara's descendants include both kșatriyas and brahmins.' 7

Ikṣvāku was born from Manu's nose when he sneezed, 'ikșvāku!' \& He had a hundred sons, the foremost of whom were the three named Vikukși, Nimi and Danḍa. Fifty of his sons led by Śakuni became protectors of the northern lands, and the other forty-eight were sovereigns of the south. 9

On the eighth day after the full moon, Ikṣvāku told his son Vikukși to fetch some meat suitable for a śräddha. Vikukși agreed and, following his father's instructions, entered the forest, where he slew many wild animals. Tired and hungry, Vikukși helped himself to a single hare, but took the rest and presented it to his father. 10

3 I have reversed the order of these two names, because Manu's son was Nābhāga, not Nabhaga. Some manuscripts indicate that both father and son share the name Nābhāga. 
Ikșvāku's family preceptor, Vasiștha, who had been invited to consecrate the offering, shouted, 'Get rid of this meat! It's unfit for sacrifice, as your wicked son has spoiled it by eating a hare. ${ }^{\prime 4} 11$ As a result, Vikukși became known as Śaśāda, 'Hare-Eater', and, because of his guru's condemnation, he was rejected by his father. 12 After the monarch died, however, Śaśāda became the virtuous ruler of all the world. $13 \mathrm{He}$ had a son known as Puramjaya. 14 But this son also had another name. 14

Long ago, in the age of Tretā, the gods and demigods fought an awful war. The gods, overcome by their mighty foe, paid homage to Lord Viṣnu. 15 Nārayyana, who has neither start nor finish and is the refuge of all the world, was gratified by them and said: 'I know already what you want, so listen to what you must do. The sage-king Śaśāda has a son called Puramijaya, a warrior of renown. An aspect of myself will descend into his body, and I'll strike down your enemies. You must therefore engage Puramjaya to destroy them.' Hearing this, the immortals bowed to Lord Viṣnu and appeared before Puramjaya. 16

The deities spoke to him as follows: 'Greetings, mighty warrior! In accordance with our request, we trust that you will help us kill our enemies. Don't disappoint the hopes of those assembled here before you.' Hearing this, Puramjaya replied, 'If I'm able to ride on the shoulders of your leader, Indra, master of all three worlds and deity of a hundred sacrifices, then I'll fight as your ally against your enemies.' Hearing this, all the deities including Indra agreed, saying, 'So be it.' 17 The god of a hundred sacrifices then took the form of a bull and Puramjaya, filled with enthusiasm, climbed upon his back. Blessed with the energy of the eternal lord, master of every moving and unmoving thing, Puramjaya fought beside the gods in their battle with the demigods and destroyed their enemies. 18 Because he overcame the demon army while riding on the back of a bull (kakut-stha), Kakutstha became his name. 19

Kakutstha's son was Anenas. Anenas's son was Pṛthu. Pṛthu's son was Viśvagaśva. His son was Cāndra. Cāndra's son was Yuvanāśva. Yuvanāśva's son was Śrāvasta, who founded the city of Śrāvastī. 20 Śrāvasta's son was Bṛhadaśva. His son was Kuvalayāśva, who, filled with the power of Viṣnu and surrounded by twenty-one thousand sons, killed the demon called Dhundhu, molester of the great sage Uttanka, and thereby became known as Dhundhumāra, 'Dhundhu's Slayer'. 21 All his sons were consumed

4 By eating the hare, Vikukși caused the rest of the food to become a mere remnant and therefore unfit for sacrifice. 
by the fire that Dhundhu breathed on them, 22 leaving only three alive: Dṛ̣hhāśva, Candrāśva and Kapilāśva. 23 Dṛ̣hhāśva’s son was Haryaśva. His son was Nikumbha. Nikumbha’s son was Saṃhitāśva. His son was Kṛśāśva, and his son was Prasenajit. His son was another Yuvanāśva. 24

This Yuvanāśva always worried that he was childless. While residing in the vicinity of the ashrams of certain sages, those holy men took pity on him and undertook a sacrifice so he might have his wish. One night during the event, before they went to bed, the sages placed a pitcher of water, consecrated with mantras, on the altar. 25 While they slept, the king, overcome by terrible thirst, entered the ashram. 26 Without waking the slumbering sages, he found the consecrated water, which had incredible powers, and drank it. 27 When the sages woke, they asked who'd drunk the water. 28 Were it King Yuvanāśva's wife, they said, she would bear a mighty and courageous son. Hearing this, the king admitted it was he who had unwittingly drunk the draught. 29 Accordingly, an infant arose in Yuvanāśva's belly and began to grow. 30 When the time arrived, the king's right flank split open and a child was born. In spite of this, the king survived. 31 'Now this baby's been delivered, to whom will he entrust it?' asked the sages. 32 At that moment, Indra, king of gods, appeared and said, 'He'll entrust it to me ( $m \bar{a} m$ dhāsyati)', 33 and so the child was called Māmuhātṛ. The king of gods put his finger in the baby's mouth and the child began to suck. Having tasted the nectar of immortality that flowed from the deity's hand, the child achieved maturity in just one day. 34 Māmudhātṛ became a universal monarch who ruled the earth with all its seven continents. 35 There is a verse about him:

'As long as the sun will rise, and as long as it keeps on shining, this whole world is said to be the realm of Yuvanāśva's son, Māṃdhātr.’' 36

\section{Māṃdhātṛ’s daughters, the sage and the fish}

Māṃdhātr married Bindumatī, the daughter of Śaśabindu, and together they had three sons, Purukutsa, Ambarīsa and Mucukunda, 37 as well as fifty daughters. $38 \mathrm{~A}$ well-versed sage by the name of Saubhari spent twelve years living underwater. $39 \mathrm{He}$ shared the pool with the king of fish, Sammada by name, who was of immense size and had innumerable offspring. Sammada's sons and grandsons frolicked by his side, behind him, in front of him and on his chest, tail and head, by day and night, while playing happily in his presence. 40 Sammada found great pleasure in this endless contact with his sons, grandsons and other offspring and, while the sage looked on, he enjoyed all sorts of games with them each day. 41 
Now, Saubhari, living underwater and seeing the daily joy this fish experienced while capering with his family, couldn't concentrate on his meditation. 'This fish is very lucky,' he said to himself. 'Even though he's had a lowly rebirth, he can play with his children and grandchildren. This has stirred a strong desire in me. Now, just like him, I want to play with children of my own.' With this thought, the sage left the water and, wishing to settle down, approached King Māṃdhātṛ to ask for one of his daughters in marriage. $42 \mathrm{As}$ soon as the king heard that the sage was coming, he rose and duly welcomed him with hospitality. Accepting the seat that had been offered, Saubhari spoke: 43

\section{Saubhari:}

I want to start a family, sire, so kindly give me one of your daughters. Please don't disappoint me. Those who, compelled by circumstance, approach the family of Kakutstha with a special wish are never turned away dissatisfied. 44 In this world are other kings to whom daughters have been born, your majesty, but your family is famous for its vow to grant the wishes of all who ask. 45

Give me one of your fifty girls, your majesty. I fear I'll suffer greatly if my petition is refused, best of monarchs. 46

\section{Parāśara:}

Hearing this, the king looked at the sage's body, wizened with age, and was about to refuse his request, but, fearing the sage's curse, lowered his gaze and pondered a while. 47

\section{Saubhari:}

What's the problem, your majesty? What I ask is not impossible. Nothing will be beyond your reach if I'm satisfied with the girl, who must be given to me in any case. 48

\section{Parāśara:}

Still fearing the sage's curse, the king made this humble reply: 49

\section{The king:}

'It's the custom of our family, sir, that a girl be given to a suitor of noble descent who pleases her. Your request is beyond the realm of my imagination, yet has arisen somehow. I was just wondering what to do in this situation.' 
When the king had spoken, the sage said to himself, 'Well, this is just another way of refusing my request. He said this because he thinks that an old man like me is unattractive to mature women, let alone young girls. So be it! I'll do what's necessary.' With this thought, he said to Māṃdhātr, 50 'This being the case, tell the palace guard to admit me to the women's quarters. If any of the girls desire me, I'll marry her. If not, I'll give up this endeavour as a waste of time.' So saying, he fell silent. 51

\section{Parāśara:}

Then Māṃdhātr, still fearing the sage's curse, ordered the palace guard to admit him to the women's quarters. 52 As that holy sage went in, he took a form more handsome than that of any siddha, gandharva or any mortal man. 53 The guard admitted him and told the girls the king, their father, had issued this instruction: 54 'This holy sage has come to ask us for a girl in marriage. I promised him that if any of my daughters chose to marry him, I would not refuse her wishes.' Hearing this, each of the girls, filled with love and passion, asserted her own superiority to win the sage, just like sheelephants in the presence of the head of the herd. 55

The girls:

'Enough, sisters! I've chosen him!' 'He was chosen by me!' 'He doesn't suit you!' 'He was created by Brahmā to be my husband!' 'I was made for him!' 'Shut up!' 56 'I chose him first!' 'I chose him as soon as he came in.' 'What's your problem?' 'He's mine!' 'No, he’s mine!'

Such was the awful fuss the princesses raised over the sage. 57 While Saubhari, whose reputation was impeccable, was surrounded by all these most affectionate girls, the guard bowed his head and informed the king of exactly what had happened. 58

\section{Parāsara:}

Learning of the situation, the king was thrown into a flurry and cried, 'Why, why has this befallen me? Tell me what to do. What have I said?', but in spite of his wishes, he eventually gave in to the sage. 59 After the great ascetic had duly married all the girls, he led them to his ashram. 60

There, he summoned Viśvakarman, the deities' artificer and master of every craft, a second Creator, and instructed him to build a palace for each girl, complete with gardens, lawns, comfortable couches and pleasant pools filled with flowering lotuses, and which resounded with the cries of wild geese, ducks and other birds. 61 When Viśvakarman, the original 
teacher of every practical art, had built the palaces, he showed them to Saubhari. 62 Next, at the command of that brilliant sage, he placed in every residence an inexhaustible heavenly treasure known as Nanda. 63 In each palace the princesses entertained their guests, retinues and dependants by night and day with amusements including endless supplies of food of all descriptions. 64

One day, the king, whose heart was troubled by affection for his daughters, wondered whether they were happy. On approaching the great sage's ashram, he beheld a row of crystal palaces, shining like the sun and set among the pleasant groves and lakes. 65 The king entered one such palace, hugged his daughter and took a seat. His eyes were brimming with tears of deep affection as he asked, 66 'Are you happy here, my darling? Does anything trouble you? Is the great sage kind to you? Are you ever homesick?'

Hearing this, the girl replied to her father, ${ }_{67}$ 'This palace is lovely, father. We have a beautiful garden and a swimming pool filled with lotuses, and the birds are always singing. The food is great, and we have the best entertainment, including massages, clothes and jewellery, plus the beds are really comfortable. Now I'm married, I have every luxury. All the same, who doesn't think fondly of the home where they were born? 68 Because of your kindness, everything has turned out splendidly. 69 There's just one thing that bothers me. This great sage, my husband, never leaves my house. Because he really likes me, he's always here, and never visits any of my sisters. 70 That must upset them, and that's my only worry.'

After she had spoken, the king went to the next palace, where he hugged the daughter who lived there, took a seat and asked her the same question. 71 Her reply was identical: she also enjoyed the luxuries of the palace and the rest, but because the sage doted on her, he never left her side or visited the others. Hearing this, the king visited each palace in turn and questioned his other daughters. 72 As they all gave the same reply, the king's satisfaction and amazement relieved the burden of his heart. Approaching holy Saubhari at a quiet moment, the king paid his respects and said, 73 'We've seen your miraculous power, sir, but we've never observed anyone perform such a prodigious feat before. How great is the reward of your austerities!' Having honoured him with these words, the king tarried there a while, enjoying the best of entertainments with that great sage, and eventually returned to his own capital. 74 
As time passed, the princesses bore the sage one hundred and fifty sons. 75 But as the rush of love he felt grew stronger every day, the sage's heart was dragged down by worries. ${ }^{6}$ 'Will my sons learn to talk nicely? Will they begin to walk? Will they grow up? Perhaps I'll see them marry. Maybe they'll have children of their own. Perhaps I'll even see my great-grandchildren.' But when he realised that such fancies ran far ahead of the day-to-day passage of time, he realised that he'd been utterly deluded: 77

\section{The sage Saubhari surrenders to Viṣnu}

'There's no end to my desires. Even if all the wishes made in ten thousand years or a hundred thousand years are satisfied, further desires will still arise. 78

My children will learn to walk, grow up, get married and have children of their own. I've seen my own sons, but now my heart yearns to see my grandsons. 79

Even if I see the birth of my grandchildren, some other desire will still arise. And even when that desire has been satisfied, what can stop the advent of the next desire? 80

I realise now that, short of death, there'll be no end to these fantasies. The heart of one attached to desire will never experience union with the highest truth. 81

My peace of mind was suddenly destroyed when I became attached to that friendly fish who shared the pool with me. As a result of that attachment I was married and, because of marriage, I have all these desires. 82

The suffering engendered by birth in a single body, and that which arises in fifty others, will be multiplied by the many sons born of the princesses whom I've married. 83

The cause of this great suffering will keep on growing with the marriages of my grandchildren, great-grandchildren and every generation after that. Marriage is indeed the source of individual anxiety. 84

The magic power resulting from the austerities I performed while living underwater was the undoing of that practice. I was swept away by my affection for my sons and all the others, and this came about because of my friendship with the fish. 85 
Freedom from attachment is the basis of liberation for ascetics. Attachment is the source of all my problems. Even an ascetic riding high on yoga falls to earth because of this, to say nothing of a less-accomplished person. 86

My heart was caught in the grip of marriage, but now I'll strive for my own welfare to escape from further troubles and avoid the suffering caused by others. 87

With my penance, I'll honour Viṣnu, creator of the world, whose form is beyond imagination, smaller than the smallest, larger than the largest, both light and dark, the lord of lords. 88

May my mind be steady, free from faults and ever set on almighty Viṣnu, who assumes all forms, whose eternal body is unmanifest and manifest, so that I may be free from future rebirths. 89

I take refuge in Viṣnu, who is all creation, purest lord of everything, who has neither start, nor end, nor middle, apart from whom no thing exists, the ultimate guru of every guru.' 90

\section{Parāśara:}

With these words, Saubhari surrendered himself, and, having abandoned his children, home, furnishings, goods, chattels and all his other possessions, accompanied by his wives, he entered the forest. 91 There, he daily undertook each practice befitting forest-dwelling sages and was cleansed of all his misdeeds. His stream of thought was purified and, having devoted himself to tending sacred fires, he became a wandering mendicant. 92 Relinquishing all actions to the lord, he attained the unborn, unchanging eternal state beyond the reach of life and death, higher than the highest. 93

Such is the story of the marriage of Māṃdhātṛ's daughters. 94 Anyone who recalls, recites, hears or understands the story of Saubhari's deeds, or causes it to be written out, will not be disrespected, or stray from perfect virtue, or take the path of error, but will be free from individual anxieties amid all distractions for the next eight lives. 95

So ends Chapter Two in Book Four of the glorious Viṣnu Purāna. 


\section{The descendants of Ambarīṣa}

\section{Parāsara:}

I'll now describe the descendants of Māṃdhātṛ's sons. 1 His first son, Ambarīṣa, had a son, Yuvanāśva. 2 His son was Harīta, from whom the Angirases known as Hāritas were descended. 3 In the lower realm of Rasātala lived gandharvas known as Mauneyas, who numbered sixty million. They plundered all the nāga clans of their most precious treasures, not to mention their sovereignty. 4 The nāga kings, deprived of power by these beings, roused Viṣnu from his slumber while he was reclining on the waters. The lord opened his eyes, which were like flowering lotuses, as he listened to the praises of all those regal deities. Bowing down before him, the nāgas asked: 'Lord, will we ever overcome our fear of these gandharvas?' The lord, the spirit without beginning, the supreme being, replied, 'The son of Māṃdhātṛ’s son Yuvanāśva has a son named Purukutsa. I'll take possession of his person and subdue these wicked gandharvas.' 5 Hearing this, the nāga kings bowed to the lord and returned to their own dominion.

The nāgas then dispatched Narmadā to summon Purukutsa 6 and bring him back to Rasātala. 7 Arriving in the lower realm, his own prowess augmented with the might of Viṣnu, Purukutsa overcame the gandharvas, then returned to his residence. 8 As a result, all the nāga kings granted Narmadā a boon that anyone who invoked her name, while calling her to mind, would have nought to fear from venomous snakes. 9 Here is the verse:

'I bow to Narmadā in the morning. I bow to Narmadā at night. Narmadā, I bow to you. Protect me from all poisonous snakes!' 10

One who recites this prayer will never be bitten by a snake by day or night, in the dark or on entering a room, and anyone who recalls Narmadā while eating will never be harmed by poison. 11 The nāga kings also blessed Purukutsa so that his lineage would never be disrupted. 12

Purukutsa and Narmadā had a son, Trasadasyu. 13 Trasadasyu's son was Sambhūta. His son Anaranya was slain by Rāvaṇa during the latter's war of global conquest. Anaranya's son was Pṛ̣adaśva. Pṛșadaśva's son was Haryaśva. His son was Vasumanas, and his son was Tridhanvan. Tridhanvan's son was Trayyāruna. His son was Satyavrata, who was given the name of Triśanku and was relegated to the status of an untouchable. 14 
Every day, during a twelve-year drought, Triśanku hung some venison in a banyan tree on the banks of the Gangā River as food for Viśvāmitra, his wife and children, so that they need never accept a gift directly from an outcaste. 15 The sage was well pleased by this and raised Triśanku to heaven in bodily form. 16

Triśankku's son was Hariścandra. His son was Rohitāśva. His son was Harita. Harita's son was Cañcu. Cañcu had two sons, Vijaya and Sudeva. Vijaya's son was Ruruka. Ruruka's son was Vṛka. 17 His son was Bāhu. It was he who, conquered by the Haihayas, Tălajanghas and other tribes, fled to the forest, accompanied by his pregnant wife. 18 One of her co-wives gave her poison to induce an abortion, 19 but as a result of the dose, the foetus remained in her womb for seven years. Bāhu died of old age in the vicinity of Aurva's ashram. 20 His wife prepared a funeral pyre and mounted it, determined to follow him in death. 21 But holy Aurva, who knew the past, present and future, rushed out of his ashram, crying, 'Abandon your foolish plan! In your womb is a future universal sovereign of great courage and prowess. He'll rule the world, perform many sacrifices and overcome his enemies. 22 Don't do this! Don't be so rash!' Hearing this, the widow abandoned her intention to follow her husband in death. 23

\section{The birth of Sagara}

That holy sage led her back to his ashram and, a few days later, she gave birth to a splendid boy, along with the poison (sa garena) she had swallowed. Aurva performed the natal rituals for the baby and named him Sagara. 24 He later invested the boy with the sacred thread, instructed him in the Vedas and other scriptures and taught him how to wield the fiery weapons named for Bhārgava. 25

One day, this gifted child asked his mother, 'Why are we living here? Where's my father?' In reply to these and other questions, his mother explained everything. 26 Later, being anxious to win back his father's kingdom, he vowed to destroy the Haihayas, Tălajanghas and the rest. First, he killed most of the Haihayas, 27 but as he was attacking the Śakas, Yavanas, Kāmbojas, Pāradas and Pahlavas, they sought refuge with Vasișțha, Sagara's own family guru. 28 Even though they were still alive, Vasisțha thought them as good as dead. 'My dear boy,' said the sage to Sagara, 'Have done with these, the living dead, who are about to meet their doom. 29 So that your vow may be fulfilled, I've caused these nations to abandon their traditions and lose contact with the brahmins.' 30 
Respecting his guru's words, Sagara agreed, but forced each tribe to adopt a different appearance. He caused the Yavanas to shave their heads, the Śakas to shave half their heads, the Pāradas to wear long hair and the Pahlavas to grow beards. He forbade these and other kșatriyas to study the Vedas or perform sacrifices with the cry of vasat. 31 Because they abandoned their traditions and were shunned by brahmins, they were reduced to the status of barbarians. 32 Sagara went back to his kingdom and ruled all seven continents of the world with uncontested authority. 33

So ends Chapter Three in Book Four of the glorious Viṣnu Purāna.

\section{Sagara's sons excavate the ocean; The story of Rāma}

\section{Parāśara:}

Sagara had two wives, Kaśyapa's daughter Sumati and the king of Vidarbha's daughter Keśinī. 1 Desiring children, the two women propitiated Aurva with all their hearts, and the sage granted them the boon that 2 one wife would have a single son, who would continue the lineage, while the other would have sixty thousand sons, saying, 'Choose whichever destiny you desire.' Keśinī chose to have a single child, and Sumati chose sixty thousand. 3 The sage agreed, and a few days later Keśinī bore a son named Asamañjas, who would continue the lineage. Vinatā's daughter Sumati had sixty thousand sons. 4 Asamañjas had a son named Amśumant. 5 From the time he was a baby, Asamañjas was ill-behaved, but his father hoped he would improve as he grew older. 6 But leaving childhood behind, his behaviour was no better, and his father gave up on him. 7 Even Sumati's sixty thousand sons followed Asamañjas's bad example. 8

Because these sons of Sagara, all aping Asamañjas's poor behaviour, left the worthy path of sacrifice in this world, the gods bowed down to Kapila, the sage who embodied every branch of knowledge, who was untouched by any fault and who was an aspect of the lord, the highest spirit. The deities explained the problem: 9 'Lord, these sons of Sagara are copying Asamañjas's bad behaviour. What will become of the world with followers like these? We beseech you to take bodily form to save the troubled universe.' Hearing this, the sage replied, 'In a few short days, they will be no more.' 10 
At about this time, Sagara began a horse-sacrifice, but during the ritual, someone stole the steed that had been guarded by his sons and hid it in a cavern beneath the earth. 12 The king sent the boys to find the beast and, following its hoofprints, each of them dug down, with great persistence, one league into the earth. 13 They finally found the horse wandering in the underworld of Pātāla. 14 They also saw the sage Kapila nearby, ceaselessly illuminating all directions with his splendour, like the lordly sun in a cloudless autumn sky. 15 Wielding their weapons, they cried, 'Here's the wretch who wronged us, the horse thief who spoiled our sacrifice! Kill him, kill him!' The sage then turned his gaze upon them for just an instant, reducing them all to ashes with fire that sprang from his own body. 16

Realising that all his sons who followed the horse had been consumed by the fiery energy of the supreme sage Kapila, Sagara dispatched Asamañjas's son Amśumant to retrieve the steed. 17 Ampsumant reached Kapila by following the path dug by his uncles, and, bowing respectfully, he praised the sage. Holy Kapila said to him, 'Go and take this horse to your grandsire. You may ask this boon of me: that your sons and grandsons may lead the Gangā down to earth from the heavens above.' 18 But Amśumant replied to the sage, 'Grant me a boon that my uncles who've been struck down by divine punishment, even though unworthy of heaven, may be admitted to that realm regardless.' 19 Holy Kapila replied, 'I've already spoken. Your descendants will conduct the Gangā down from heaven to earth. When your uncles' bones and ashes are touched by the water of that sacred stream, they'll ascend to heaven. Such is the efficacy of the water that flows across the toes of blessed Viṣnu. 20 It not only yields all happiness for those who bathe there purposely, but even one whose bones, skin, sinews, hair or other body parts fall by chance to the ground in its vicinity will immediately go to heaven when they die.' Hearing this, Amśumant bowed to the holy sage, and returned the horse to his grandsire's sacrifice. 21 Once Sagara had retrieved the beast, he was able to complete the ritual. 22 Out of affection for the boys, he raised the chasm that they had dug, now named Sāgara in their honour, to the status of his own son. ${ }^{5} 23$

Aṃśumant's son was Dilīpa. 24 It was Dilīpa’s son Bhagīratha who led the Gangā to earth from heaven and named it Bhāgīrathī. 25 Bhagīratha's son was Śruta. His son was Nābhāga. His son was Ambarīṣa. His son was Sindhudvīpa. Sindhudvīpa's son was Ayutāyu. His son was R.tuparṇa, the

5 I have had to add some words of explanation to this translation. Later, this chasm filled with water and formed an ocean, known as sāgara in Sanskrit. 
companion of Nala and expert in the game of dice. ${ }^{6} 26$ Rtuparna's son was Sarvakāma. His son was Sudāsa. Sudāsa's son, Saudāsa, was also known as Mitrasaha. 27

\section{Saudāsa becomes a rākṣasa}

One day, Saudāsa was hunting in the forest when he saw two tigers. 28 These beasts had killed all the deer in the vicinity, so Saudāsa shot one with an arrow, 29 but, as it lay dying, it turned into a rākșasa of terrible appearance with a hideous expression. 30 The surviving tiger-rakșasa roared, 'I'll have revenge on you!', and vanished from sight. 31 Some time later, this Saudāsa was performing a sacrifice. When the great sage and sacrificial expert Vasișțha had stepped away for a moment, the tiger-rākșasa disguised himself as the sage and said to the king, "When the sacrifice is over, all the food, including the meat, should be given to me to eat. Have it cooked for me, and I'll be back in just a minute.' So saying, he departed. 32

This same rākșasa then disguised himself as a cook and, instructed by the king, prepared a dish of human flesh, which he presented to the sovereign. 33 Saudāsa accepted the flesh served on a golden platter and waited for Vasiștha to return. When the real sage came back, the king offered him the platter. 34 But the sage said to himself, 'How rude of the king to give this meat to me. What is it, anyway?' Vasiștha began to meditate and, realising it was human flesh, his mind spun round with fury. He cursed the king, saying, 'You know that we ascetics can't eat human flesh, but you gave it to me anyway! Now your heart will crave such food!' 35 But the king snapped back, 'It was you who ordered me to cook it!'

Wondering how he could have said such things, the sage began to meditate again. 36 With the insight gained through contemplation, he discovered the truth of the matter and took pity on the king: 'You won't have to eat this food for ever,' he said, 'Just twelve years.' 37 The king, holding water in his cupped hands, was about to curse the sage when his consort Madayantī soothed him with these words, 'The holy sage is our guru! You can't curse a preceptor who is like our personal deity!' The king couldn't throw the cursed water on the ground for fear of damaging the crops, nor could he throw it into the air, as he worried it might disperse the clouds, so he poured it on to his own feet. 38 The water, imbued with all the king's own anger, burned his feet so badly that they were blotched with black and white. As a

6 Nala is a famous character in the Mahäbhārata. 
result, he became known as Kalmāṣapāda, 'Blotch-Foot'. 39 In accordance with Vasisțha's curse, every day at the sixth watch, the king became a rākṣasa and, prowling in the forest, devoured multitudes of people. 40

One day, the rākșasa spied a sage enjoying intercourse with his wife, as became the season. The frightened couple saw the dreadful creature and tried to flee, but the rākșasa seized the brahmin. 41 His wife pleaded with the demon repeatedly, 'Have mercy on us! You're the great king Mitrasaha, crown-jewel of Ikṣvāku's lineage, not a rākṣasa at all. You understand women's pleasure. Please don't eat my husband before my desire has been satisfied!' But even as she made these varied pleas, he ate the brahmin anyway, just as tigers devour their prey. 42 The brahmin's wife, filled with rage, cursed the king, saying, 'Because you ate my husband before I was satisfied, your end will come while you're making love!' With this, she entered the flames. 43

Twelve years later, the king was freed from the sage's curse, but when he yearned for the company of a woman, Madayanti reminded him what the brahmin's wife had said. 44 The king thereafter avoided intercourse and, being childless, asked Vasisțha for a son, and the sage himself conceived a son with Madayantī. Another seven years passed by, but as the infant remained unborn, the queen struck her belly with a stone (asman). This finally induced the child's birth, and they called him Aśmaka. 45

\section{Aśmaka's descendants}

Aśmaka had a son called Mūlaka. When the earth was being cleansed of kșatriyas, Mūlaka survived by protecting (kavaca) himself with naked women $(n \bar{a} r \bar{\imath})$. That's why he's also known as Nārīkavaca. 46 Mūlaka's son was Daśaratha. His son was Ilivila. His son was Viśvasaha. His son was Khațvānga, also known as Dilīpa. It was he who, petitioned by the deities, destroyed their enemies in their war in heaven against the demigods. As he'd done this favour for the gods, they urged him to request a boon. Khațvānga said, 'If I must accept your offer, tell me how long I'll live.' The deities replied at once, 'You'll only live for one more minute.' Thus addressed, and imbued with the quality of lightness, he was carried down to the world of men on a comfortable sky-going chariot. On arrival, Khaḍvānga said, 'My own self is no dearer to me than being in the presence of brahmins. I've never strayed from the traditions of my order. I've always seen the eternal, indivisible unity in all creation, embracing gods, mortals, animals, plants and the rest. May I, therefore, with unfaltering steps, reach the lord, 
the very deity on whom sages set their hearts.' So saying, he merged into the most senior of all the gods, the lord whose form is beyond description and who is all existence, the highest spirit known as Vàsudeva, and there Khațvānga achieved absorption. 47

People hear this verse about King Khațaanga sung by the Seven Sages long ago:

'There'll never be another in the world like Khațvanga, who came from heaven down to earth to live for just one minute. With his intellect and generosity, he was one with all three worlds.' 48

\section{The story of Rāma}

Khațvānga's son was Dīrghabāhu. His son was Raghu. His son was Aja. His son was also called Daśaratha. For the preservation of the world, Lord Viṣnu, who has a lotus at his navel, manifested aspects of himself as the four sons of Daśaratha in the forms of Rāma, Lakṣmaṇa, Bharata and Śatrughna. When Rāma was just a boy, while journeying to protect Viśvāmitra's sacrifice, he slew the demoness called Tățakā. 49 At the sacrifice itself, he drove off the rākșasa Mārīca with a shower of arrows. He killed the other rākșasas led by Subāhu, and cleansed Ahalyā of her sins with just a glance. In the palace of Janaka, he lifted Siva's bow, snapped it easily and won King Janaka's daughter Sìtā, born of Earth, as reward for his prowess. 50 He stripped the courage, strength and pride from Paraśurāma, who destroyed the kșatriyas, and consumed the clan of Haihayas like a fire. 51 On his father's orders, Rāma entered the forest with his wife and brother, giving not a thought to the sovereignty he'd relinquished. 52 There he slew Virādha, Kharadūṣaṇa, Kabandha and other rākșasas, as well as Vālin, king of monkeys. 53 Ràma built a bridge across the sea and destroyed the race of rākșasas. He then returned to Ayodhyā with King Janaka's daughter Sītā, who'd been seized by ten-headed Rāvana and whose blemish was removed after that rākșasa's demise. Sìtā's purity was confirmed when she passed unharmed through fire, while all the deities sang her praises. 54

Bharata, too, slew thirty million fearsome gandharvas in order to subdue their realm. Śatrughna killed the brave and powerful rākșasa lord named Lavana, son of Madhu, and occupied his capital, Madhurā. 55 By these and other feats of unequalled strength and courage, Rāma, Lakșmaña, Bharata and Śatrughna destroyed those wicked beings and guaranteed security for all the world. Having done so, they ascended again to heaven. 56 
The inhabitants of Rāma's kingdom, Kosala, loved all four brothers, each an aspect of Viṣnu, and, with their hearts devoted to the lord, they, too, achieved that heavenly state. 57

\section{Rāma's descendants}

Rāma had two sons, Kuśa and Lava. Lakṣmaṇa's sons were Angada and Candraketu. Takșa and Puskara were Bharata's sons. Subāhu and Śūrasena were the sons of Śatrughna. Kuśa's son was Atithi. Atithi's son was Nișadha. Nișadha's son was Nala. His son was Nabhas. Nabhas's son was Puṇ̣arîka. His son was Kṣemadhanvan. His son was Devānīka. His son was Ahīnagu. His son was Ruru. His son was Pāriyātra. Pāriyātra's son was Dala. Dala's son was Chala. His son was Uktha. Uktha's son was Vajranābha. His son was Śan̉khanābha. His son was Vyutthitāśva. He had a son, Viśvasaha. 58 His son was Hiranyanābha, the great ascetic master and disciple of the sage Jaimini, from whom Yajiñavalkya learned the art of yoga. 59 Hiranyanābha's son was Puṣya. His son was Dhruvasaṃdhi. His son was Sudarśana. His son was Agnivarṇa. His son was Śīghraga. His son was Maru, who, having established his ascetic practice, dwells in the village of Kalāpa to this very day. In some future age, he will reestablish the kṣatriya order in the Solar Dynasty. His son was Prasuśruta. His son was Susandhi. His son was Amarșa. His son was Mahasvant. His son was Viśrutavant. His son was Brhadbala, who was slain by Abhimanyu, son of Arjuna, in the Bhārata war. 60

I've given you a summary of the kings of Ikṣvāku's lineage. By hearing their accomplishments, you'll be freed from all misdeeds. 61

So ends Chapter Four in Book Four of the glorious Viṣnu Purāna.

\section{The legend of Nimi: Why we blink}

\section{Parāśara:}

Ikșvāku's son Nimi selected Vasiștha as the priest to officiate at a thousandyear-long sacrifice. 1 But Vasisțha said to him, 'I've already been engaged by Indra to conduct a sacrifice of five hundred years for him. You must wait, but I'll come to be your priest as soon as it is finished.' After Vasiștha had spoken, King Nimi said nothing. 2 Believing that he had Nimi's agreement, the sage Vasisțha performed the sacrifice for Indra, king of the immortals. 3 Nimi, however, invited other sages including Gautama to conduct his 
ritual. When Indra's sacrifice had been completed, Visisțha hastened back, believing he would conduct the sacrifice for Nimi. When he saw that the position of officiating priest had been given to Gautama, he cursed the king, who was asleep at the time: 'Because you gave this task to Gautama without informing me, you'll exist no more in bodily form!' 4 On waking, the king said, 'As this irascible guru has cursed me without warning while I slept, and I knew nothing of the matter, may he also cease to exist in physical form!' Uttering this counter-curse, the monarch left his body. 5 As a result of Nimi's imprecation, Vasistha's life force merged with that of the deities Mitra and Varuna. One day, while spying on the apsaras Urvaśî, the two deities experienced an ejaculation of semen and, as a result, Vasisțha gained at once another body. 6 Nimi's remains, treated with the finest oils and fragrances, showed no sign of putrefaction or decay, and looked as though he'd only just departed.

At the conclusion of the sacrifice that Nimi had undertaken, the priests said to the deities who arrived to collect their share, 'You should grant a wish to the person who initiated this ritual.' The deities agreed, and Nimi's voice was heard to say, 7 'You can end the torrent of suffering endured by all the world. There is no greater pain on earth than the parting of body and soul. I therefore wish to remain in the eyes of all living things, but never again shall I take a physical form.' Hearing this, the deities caused Nimi to appear in the eyes of every living creature, 8 and that's why they all blink (nimesa).

\section{Nimi's descendants}

As Nimi had no son, the sages feared the absence of a king. They therefore rubbed his body with a firestick 9 and thus brought forth a baby boy. Because the child was generated (janana) in this manner, he was called Janaka, 10 and because his father was without a body (videha), the boy was known as Vaideha. He also had another name, Mithi, as he'd been brought forth by rubbing (mathana) with a stick. Janaka's son was Udāvasu. Udāvasu's son was Nandivardhana. His son was Suketu. His son was Devarāta. His son was Bṛhaduktha. His son was Mahāvīrya. His son was Satyadhṛti. His son was Dhṛstaketu. Dhṛsțaketu’s son was Haryaśva. His son was Maru. Maru's son was Pratibandhaka. His son was Kṛtaratha. His son was Kṛti. His son was Vibudha. His son was Mahādhṛti. His son was Kṛtirāta. His son was Mahāroman. His son was Suvarṇaroman. His son was Hrasvaroman. His son was Sīradhvaja. When Sïradhvaja was ploughing the sacrificial ground to obtain a son, a daughter, Sìtā, appeared at the tip of his ploughshare. 
Sīradhvaja's brother, the king of Sāṃkāsiñ, was called Kuśadhvaja. Sīradhvaja's descendant was Bhānumant. Bhānumant's son was Śatadyumna. His son was Śuci. He had a son named Ūrjavaha. 11 His son was Satyadhvaja. His son was Kuni. Kunị's son was Añjana. His son was Retujit. His son was Arișțanemi. His son was Śrutāyus. Śrutāyus's son was Supārśva. His son was Samjjaya. His son was Kṣemāri. His son was Anenas. His son was Mīnaratha. His son was Satyaratha. His son was Sātyarathi. Sātyarathi’s son was Upagu. His son was Śāśvata. His son was Sudhanvan. His son was Subhāṣa. His son was Suśruta. His son was Jaya. The son of Jaya was Vijaya. His son was called R.ta. R.ta's son was Sunaya. His son was Vìtahavya. His son was Dhṛti. Dhṛti’s son was Bahulāśva. His son was Kṛti and, with Kṛti, the lineage of Janaka came to an end. 12

Such were the kings of Mithilā, known as the Maithilas, most of whom were sovereigns who had recourse to the knowledge of the Self. 13

So ends Chapter Five in Book Four of the glorious Viṣnu Purāna.

\section{The Lunar Dynasty}

\section{Maitreya:}

Master, you've described the Solar Dynasty to me, but I'd like to hear in detail about the monarchs in the lineage of the Moon. 1

The offspring of these famous men are celebrated to this day, so it would befit you, kind and gracious brahmin, to describe them all to me. 2

\section{Parāśara:}

Listen, you tiger of a sage, to the lineage of the beaming Moon in which successive famous kings arose. 3

This dynasty is resplendent with sovereigns such as Nahuṣa, Yayāti and Kărtavirya Arjuna, who were richly blessed with qualities of great strength, courage, dignity, integrity and endeavour. Listen and I'll describe them for you. 4

Brahmā, creator of the universe, born from the lotus at the lily-like navel of Lord Nārāyaña, had a son, Atri. Atri's son was Soma the Moon. 5 Lotus-born Lord Brahmā consecrated Soma as sovereign over all plant life, the brahmins and constellations. 6 


\section{Soma abducts Tārāa}

Soma conducted a rājasūya - a royal coronation sacrifice-and, with the power he gained thereby and because he ruled a vast domain, he grew arrogant. 7 Proud and haughty, Soma abducted Tārā, wife of Bṛhaspati, preceptor of all the deities. 8 Even though he was urged repeatedly by Brihaspati, chastised by Lord Brahmā and implored by all the heavenly sages, he refused to give her back. 9 Because of his enmity towards Bṛhaspati, the sage Uśanas took Soma's side. 10 Lord Rudra, who had acquired his knowledge of the Vedas from Angiras, allied himself with Brihaspati. 11 Jambha, Kumbha and all the other Dānava and Daitya hordes, following Uśanas, made great efforts in Soma's cause. Indra, with the backing of all the divine armies, supported Brhaspati. 12 Thus, two sides fought a terrible battle over Tărā known as the Tărakā War. The deities led by Rudra loosed all their weapons against the demigods, as did the Dānavas in return. 13

This whole world, with hearts atremble at the shock of the battle between the gods and demigods, sought refuge with Brahmā. 14 The lord commanded Uśanas, the demigods, Rudra and the deities to desist and returned Tàrā to

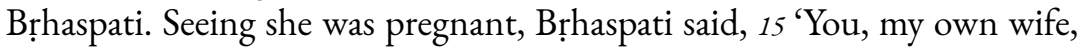
shall not bear the son of another man. Get rid of it! I've had enough of your audacity!' 16 Thus addressed by her husband, and even though she'd been faithful to him, she obeyed his orders and gave birth to the infant in a bed of reeds. 17

As soon as the child was born, his splendour outshone the brilliance of the deities. 18 Seeing both Brihaspati and Soma overcome with affection for the child because of his magnificence, the gods became suspicious and

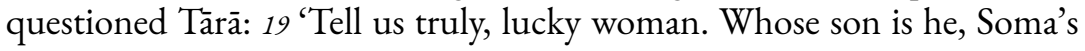
or Bṛhaspati's?' Tărā, hearing this, was too ashamed to answer. She said nothing to the gods, even though they questioned her repeatedly. The child himself desired to curse her, saying, 'Wicked woman! Why don't you tell them who my father is? This very day, I'll inflict such punishment on you, filled with this false modesty, that no woman will ever be so slow to speak again.' 20 But Lord Brahmā, grandsire of the world, stopped the boy and questioned Tărā himself, 'Tell me, my dear, whose child it is, Soma's or Bṛhaspati's?' Hearing this, and frozen with embarrassment, she confessed the child was Soma's. 21 The blessed Moon, lord of constellations, heaved a sigh of relief and his cheeks shone again with loveliness. He hugged the boy and cried aloud, 'Well done, well done, my son. How wise you are!' and named him Budha, 'clever'. 22 


\section{Purūravas's affair with the apsaras Urvaśi}

I previously described how Budha had a son named Purūravas with Ilā, who was generous, devout and energetic. ${ }^{7}$ Now, the apsaras Urvaśī, cursed by Mitra and Varuna, chose to live in the world of men, where she beheld this truthful, handsome Purūravas. 23 At first sight, she shed her pride and lost all interest in the pleasures of heaven. Setting her heart on this mortal man, she approached him. 24 When Purūravas saw Urvaśi imbued with qualities such as tenderness and loveliness, which outshone every woman in the world, her charming way of walking and her sweetest smile, he lost his heart to her. 25 They fell in love, had eyes for no-one else and abandoned all other interests. 26 Summoning his courage, King Purūravas

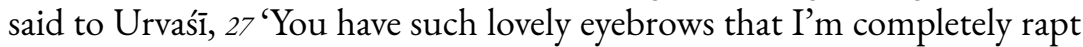
in you! Take pity on me and love me in return.' Hearing this, Urvaśi shyly stammered her reply, 28 'We'll be lovers, but you must first accept my terms.' 29 'State them!' said the king. 'First, I keep two pet sheep beside my bed,' Urvaśî explained, 'They're like my sons, and must never be removed. Second, I must never see you naked and, third, butter is the only thing I eat.' 'Agreed!' replied the king.

In the region of Alakā, in Caitraratha and other forests and in lakes ablaze with freshest lotuses, the king enjoyed himself with Urvaśi for sixty-one years, his pleasure increasing daily. 30 Urvaśi shared these delights with him and, as she loved him more each day, she had no desire to return to the immortals' realm. 31

In her absence, however, heaven lost its charm for the other apsarases, siddhas and gandharvas. 32 Accordingly, one night, Viśvāvasu, who knew of Urvaśī and Purūravas's agreement, accompanied by some gandharvas, stole a sheep from Urvaśî's bedside. 33 As it was carried through the air, Urvaśi heard it bleating and cried aloud, 'Someone's stealing one of my boys! Who'll protect me, a helpless woman?' The king heard her cries, but fearing she would see him naked, didn't go to her assistance.

Sometime later, the gandharvas stole her other sheep, and again Urvaśi heard it bleating as it was carried off. 'A helpless woman who has no husband, I have to rely on cowards!' Such were her anguished cries. 34 The king, unable to restrain himself and thinking he'd be safe in the darkness, seized his sword and charged in, shouting 'Stop, thief! Stop! I'll kill you!' 35 At that moment, the gandharvas caused a blinding flash of light and in the

7 See Viṣnu Purāṇa, 4.1.12. 
glare Urvaśi beheld the naked king. As their pact had now been broken, she vanished in an instant. 36 The gandharvas then dropped the sheep and flew back up to heaven. 37 The king caught both animals and, feeling pleased with himself, went back to bed. It was only then that he discovered Urvaśi had vanished. 38 Unable to see her, the frenzied king, still naked, rushed about in search of her.

At last he found Urvaśí in Kurukșetra, swimming in a lotus pool with four other apsarases. 'Hey! That's my wife!' he shouted in great excitement, 'Wait, you hard-hearted woman. Wait! Speak to me!', and so on. 39 But Urvaśĩ merely replied, 'That's enough of your ill-considered actions. I'm pregnant, sire. Come back next year and you'll have a son. We'll then spend one last night together.' Hearing this, the joyful king returned to his dominion. 40 Urvaśi then explained to the other apsarases that she'd been in love with him and stayed with him for many years. 'You're right about his handsome looks,' the apsarases said, 'We'd gladly live with him forever!'

One year later, the king returned and Urvaśi presented him with a son, Āyus. 41 They spent that night together and Urvaśi conceived five more boys. 42 'Because all the gandharvas favour me,' she said to the king, 'they'll grant your majesty a boon. Just ask for anything you want.' 43 'I've conquered all my enemies,' the king replied, 'My five senses are still sharp, I've a family of my own, with wealth and power beyond all measure. I wish for nothing other than to share a realm with Urvaśī. I only want to be with her.' 44

Hearing this, the gandharvas gave him a brazier in which a fire was burning, 45 with this instruction, 'In accordance with sacred tradition, divide this fire in three. Perform a perfect sacrifice to accomplish your desire of sharing a realm with Urvaśí. Then your wish will certainly be fulfilled.' Hearing this, the king took the brazier with the fire and went into the forest, but when he got there, he thought, 'How stupid of me! I've brought the brazier, but I should have brought Urvaśi as well.' With this, he left the fire and returned to the city. 46

In the middle of the night, the king woke up with this thought, 'The gandharvas gave me the brazier so I could share a realm with Urvaśi, but I left it in the forest. I should go back and get it.' With this, he got up, but when he reached the forest, the brazier was nowhere to be seen. In its place, however, stood two trees, an aśvatthama with a sami growing up its middle. Seeing this, the king said to himself, "This is where I left the brazier, but it's turned into these two trees. They must be fire in another form, so 
I'll take them back to the city and make a firestick out of them. I'll then use the stick to start a fire and make oblations into that.' With this thought, he returned to the capital once more and set to work. 47

Measuring with his thumb as he chanted the Gāyatrī mantra, he made a firestick twenty-four inches long, as that's the number of syllables in the verse. He then used the stick to start a fire. The king divided the fire in three as required by scripture, and made oblations into each, stating that his goal was to share a realm with Urvaśī. 48 By undertaking the fire sacrifice many times in accordance with tradition, he finally reached the dominions of the gandharvas, and was never parted from Urvaśi again. 49 That's why they say, 'In the beginning there was but a single fire, but during the current Manvantara, Ilä's son divided it in three.' 50

So ends Chapter Six in Book Four of the glorious Viṣnu Purāna.

\section{King Jahnu drinks the Gangā dry}

\section{Parāśara:}

Purūravas had six sons, Āyus, Dhīmant, Amāvasu, Viśvāvasu, Śatāyus and Śrutāyus by name. 1 Amāvasu had a son called Bhīma. 2 Bhīma's son was Kāñcana. Kāñcana’s son was Suhotra. His son was Jahnu. Seeing that his entire sacrificial enclosure had been flooded with water from the Gangā River, Jahnu, his eyes red with fury, deployed his supreme powers of concentration to draw the holy spirit of the sacrifice to himself. He then drank the Gangā dry. 3 The divine sages placated him, giving him the river as his daughter. 4

Jahnu also had a son, called Sumantu. His son was Ajaka. His son was Balākāśva. His son was Kuśa. Kuśa had four sons: Kuśāmba, Kuśanābha, Amūrtaraya and Amāvasu. 5 Of these, Kuśāmba undertook austerities, hoping for a son who would be Indra's equal. Seeing his awesome practices and thinking there could never be another being with prowess equal to his own, Indra appeared himself as Kuśāmba's son. 6 He was born as Gādhi, also known as Kauśaki. 


\section{Mother and daughter swap gruel}

Gādhi had a daughter named Satyavatī, whom Ṛcika, Bhṛgu's scion, wished to marry. $7 \mathrm{Ga} d h i$, however, unwilling to give the girl to a cantankerous old brahmin, demanded a bride-price of one thousand fleet-footed horses, each as white as the moon and each with one black ear. 8 The sage Rcika acquired a thousand such steeds from Varuna at the sacred ford of Aśvatīrtha, presented them to Gādhi and so married his daughter. In order that Satyavatī might conceive a son, R. cika prepared some gruel for her. 9 Satyavatī pleased the sage, so he made a second bowl of gruel for her mother, so that she, too, might have a son who would become a peerless warrior. 10 'This gruel is yours, and the other is for your mother. Don't mix them up.' So saying, the sage set out for the forest. 11

When it was time to eat, Satyavatî's mother said, 'Daughter, every father wants his son to be outstanding, and no son should be outdone by his mother's brother. Give me your gruel and you eat mine. $12 \mathrm{My}$ son is destined to rule the world, while yours will be a brahmin. How much strength, courage or glory would such a son possess?' Hearing this, Satyavatī gave her gruel to her mother. 13

When the sage returned from the forest, he looked at Satyavatī 14 and said, 'You wicked girl! Why have you done wrong? You look terrible. You must've eaten the gruel I made for your mother. You shouldn't have done that! 15 I imbued her gruel with glory, strength and courage. In yours I put tranquillity, knowledge, patience and all the other virtues of a brahmin. Because you ate the wrong one, your son will lead a fearsome warrior's life, obsessed with war and death. Your mother's son will be a brahmin who delights in peace.' Hearing this, Satyavatī clutched her husband's feet, 16 and in that abject position, implored him, 'Husband, I didn't know what I was doing. Have pity on me. Don't let my own son be like that. Kindly let it be my grandson.' Hearing this, that wise man acceded to her request. 17

In due course, Satyavatī gave birth to Jamadagni, and her mother bore Viśvāmitra. Satyavatī became the river known as Kauśakī. Jamadagni married Reṇukā, the daughter of Reṇu, born in the lineage of Ikṣvāku. Jamadagni and Reṇukā had a son named Paraśurāma, who wiped out all the kṣatriyas and was an aspect of Lord Nārāyaṇa, preceptor of the universe. 18 The gods gave Viśvāmitra a son, Śunahśepa, in the lineage of Bhṛgu. His son was called Devarāta. Later, Viśvāmitra had other sons, 
named Madhucchanda, Jayakṛta, Devāștaka, Kacchapa and Hārītaka. 19 From these descended many branches of the line of Kauśika, linked by marriage to families of other sages. 20

So ends Chapter Seven in Book Four of the glorious Viṣnu Purāna.

\section{The descendants of Purūravas's son Āyus}

\section{Parāśara:}

Purūravas's eldest son, Âyus, married the daughter of Rāhu. 1 Āyus had five sons with her: Nahușa, Kșatravṛddha, Rambha and Raji, with Anenas as the fifth. Kṣatravṛddha's son was Suhotra. 2 He had three sons, Kāśya, Leśa and Gṛtsamadās. Gṛtsamadās's son, Śaunaka, established the system of four communities. 3 Kāśya's son was the king of Kāśî. His son was Dīrghatamas. Dìrghatamas's son was Dhanvantari, who achieved great things and in every subsequent rebirth mastered each branch of knowledge. Lord Nārāyaṇa granted him a boon 4 that, in this life, he would be born in the clan of Kāsirāja, would compose the complete eightfold Âyurveda and would enjoy a portion of the sacrifice. 5

Dhanvantari's son was Ketumant. Ketumant's son was Bhīmaratha. His son was Divodāsa. His son was Pratardana. After the destruction of the Bhadraśrenya clan, he vanquished all his foes and hence was called Śatrujit, 'Enemy-Conqueror'. 6 His father affectionately called him vatsa or 'darling', so he was also known by that name. Because he was dedicated to truth, he was called Rtadhvaja, 'Whose Banner is Honesty'. Further, as he acquired a horse (aśva) named Kuvalaya, he was known around the world as Kuvalayāśva. 7 This Vatsa had a son called Alarka, about whom people still sing this verse:

'For sixty thousand years, and six thousand more, none other than young Alarka ruled the world.' 8

This Alarka had a son called Sannati. His son was Sunītha. His son was Suketu. His son was Dharmaketu. His son was Satyaketu. His son was Vibhu. His son was Suvibhu. His son was Sukumāra. His son was Dhṛștaketu. His son was Vainahotra. His son was Bhārga. Bhārga's son was Bhārgabhūmi, who further developed the system of four communities.

I've told you about the kings of Kāśi. Now you'll hear of Raji's offspring. 9

So ends Chapter Eight in Book Four of the glorious Viṣnu Purāna. 


\section{9. Āyus's son Raji usurps Indra}

\section{Parāśara:}

Raji, son of Âyus, had five hundred sons of peerless strength and courage. 1 At the outbreak of the war between the gods and demigods, each side strove to overcome the other. Both questioned Brahmā, saying, 2 'Lord, which side will be victorious in this war between us?' 3 Lord Brahmā replied, 'The side for which Raji takes up arms and fights.' The Daityas therefore went to Raji and requested his assistance. 'I'll fight for you if, when we overcome the gods, I become your king,' he replied. Hearing this, they said, 'We cannot say one thing and do another. Prahlāda is our king and we fight for him.' With this, the demigods departed. After they had left, the gods then put the same question to the king. Raji promised to help them and they agreed to accept him as their sovereign. 4

Supported by the army of the gods and wielding many powerful weapons, Raji vanquished all the forces of the demigods. 5 When his rivals had been overcome, Indra pressed his forehead to Raji's feet and said, 'Because you saved us from calamity, you're like a father to us. You're unexcelled in all the worlds. I, sovereign of all three realms, am but your son!' 6 The king said with a laugh, 'So be it! Such a respectful salutation, filled with varied words of flattery, cannot be disregarded, even when it's spoken by an enemy.' So saying, he returned to his own capital 7 and Indra, deity of a hundred sacrifices, conferred sovereignty on him there. 8

After Raji died and went to heaven, the sage Nārada encouraged Raji's sons to petition Indra, who ranked as one of their own brothers, to confer sovereignty on them in accordance with tradition. 9 As Indra refused their request, those mighty beings defeated him, usurping his position for themselves. 10

Some days later, Indra, now deprived of sovereignty over the threefold worlds and no longer receiving his portion of the sacrifice, met Brhaspati in a secluded place and said to him, 11 'It would be nice if you could give me some of the leftover oblations to keep me going —-something the size of a dried date would do.' Hearing this, Brhaspati replied, 'If that's the case, you should've told me earlier. There's nothing I wouldn't do for you. I can get your position back in a couple of days.' So saying, Brhaspati performed a sacrifice each day to sow confusion in the brothers' minds and to restore Indra's ardour. When the five brothers were overcome by mental turmoil, they became the brahmins' rivals, rejected true religion and turned away 
from the teachings of the Vedas. 12 As soon as they abandoned dharma, Indra was able to destroy them. With the energy that his preceptor, Brihaspati, had restored to him, he bestrode the threefold world once more.

Anyone who hears how Indra lost, then won his status back again, will never suffer anguish should he lose his own position. 13

Āyus's third son, Rambha, had no offspring. His second son, Kṣatravṛddha, had a son, Pratikșatra. His son was Samjaya. His son was Jaya. His son was Vijaya, and his son was Kṛta. His son was Harșavardhana. Harșavardhana’s son was Sahadeva. His son was Adīna. His son was Jayatsena. His son was Samkrtit. His son was Kșatradharman. These were the descendants of Kṣatravṛddha. Next I'll describe the lineage of Nahușa. 14

So ends Chapter Nine in Book Four of the glorious Viṣnu Purāna.

\section{0. Āyus's grandson Yayāti exchanges old age for youth}

\section{Parāśara:}

Yati, Yayāti, Samyyāti, Āyāti, Viyāti and Kṛti were Nahuṣa's six brave and powerful sons. 1 As Yati had no desire for sovereignty, Yayāti became the king. 2 He married Uśanas's daughter Devayānī and Śarmișthā, the daughter of Vṛsaparvan. There is a verse about their offspring: 3 'Devayāni had two sons, Yadu and Turvasu. Vṛsaparvan's daughter Sarmișțā had three, Druhyu, Anu and Puru. ${ }^{8} 4$

Yayāti was cursed by the poet Uśanas to grow old before his time. 5 With the intervention of mighty Indra, whom he had propitiated, Yayāti was able to transfer his old age to another person. Accordingly, he said to his eldest son, Yadu, 6 'Your maternal grandfather has cursed me to grow old prematurely, but with Indra's permission, I can transfer my old age to you for a thousand years. I'm not yet sated with the pleasures of life and want to enjoy myself by taking on your youthfulness. You can't refuse me!' Hearing this, Yadu had no desire to accept Yayāti's old age, so his father cursed him, saying, 'Your descendants will never be fit to rule.' 7 The king then asked Turvasu, Druhyu and Anu to exchange their youth for his old age, but they all refused, so he cursed them as well. 8

8 See Mahābhärata, 1.90.9. 
Yayāti then made the same request to Śarmișțhā's youngest son, Puru. Having a generous disposition, Puru bowed to his father and said with respect, 'You're doing me a great favour.' So saying, Puru accepted Yayāti's old age and gave his father his youth. 9 Having acquired Puru's youthfulness and without offending against virtue, Yayāti indulged in the pleasures of life as suited to his desire, age and energy, while properly defending his subjects. 10

Enjoying himself with the apsaras Viśvācī and with his own wife, Devayānī, he daily thought his desires would eventually cease. 11 Every day, however, pursuing these pleasures, his mind turned again to his exquisite yearning. 12 People sing these verses in this regard:

'Desires cannot be satisfied when you indulge them. A fire flares up with every offering of butter. 13

All the rice, barley, gold, cattle and women in the world cannot satisfy a man. He must therefore cast off desire. 14

If a man rejects a dim view of the world, then, seeing everything as equal, he'll find pleasure all around. 15

The feeble-minded person finds it hard to shun desires; they don't grow old with age. The wise abjure such yearning, as then they're filled with happiness. 16

Hair grows white with age, and with age the teeth decay. But love of money and love of life never wither, even as one grows old. 17

I've spent a thousand years, my heart obsessed with pleasure, But every day desire for more still grows in me. 18

I'll therefore abandon these desires and set my mind on the Absolute. Free from dualities and selfishness, I'll roam with wild animals.' 19

\section{Parāśara:}

Yayāti eventually retrieved his old age from Puru and returned his son's youthfulness. He then anointed Puru as king and retired to the forest to undertake austerities. 20

He invested Turvasu as regent over the south-east, Druhyu over the west and Yadu over the south. 21 
He made Anu regent of the north and, having consecrated Puru as king of all the world, retreated to the wilderness. 22

So ends Chapter Ten in Book Four of the glorious Viṣnu Purāna.

\section{Yayāti’s son Yadu}

\section{Parāśara:}

I'll now describe the lineage of Yayāti's first son, Yadu, in which Lord Viṣnu revealed an aspect of himself, who has no start or finish and whose immeasurable greatness is always praised in order to obtain each possible reward by all the inhabitants of the universe, including humankind, siddhas, gandharvas, yakṣas, rākṣasas, guhyakas, kimpuruṣas, apsarases, serpents, birds, Daityas, Dānavas, Rudras, Vasus, the Aśvins, Maruts and divine and brahminical sages, who yearn to escape from cyclical existence and who wish for virtue, wealth, love and liberation. 1 There is a verse in this regard:

'One who hears about the lineage of Yadu, in which the formless highest Absolute known as Viṣnu appeared, will be freed from all misdeeds.' 2

The four sons of Yadu were called Sahasrajit, Kroștu, Nala and Raghu. Sahasrajit's son was Śatajit. His three sons were Haihaya, Hehaya and Venuhaya. Haihaya's son was Dharma. His son was Dharmanetra. His son was Kunti. Kunti's son was Sāhaṃji. His son was Mahișmant. 3 His son was Bhadraśrenya. His son was Durdama. His son was Dhanaka. Dhanaka's four sons were Kṛtavīrya, Kṛtāgni, Kṛtadharma and Kṛtaujas. Kṛtavīrya’s son was thousand-armed Arjuna, lord of seven continents. It was he who, having worshipped Dattātreya, an aspect of the lord born in the lineage of Atri, requested and received these boons from him: a thousand arms, the constant practice of virtue, victory over all the world by means of truth, talent to rule with justice, invincibility in the face of enemies and death only at the hands of a person with global fame. $4 \mathrm{He}$ ruled the whole world superbly, including all the continents, and performed ten thousand sacrifices. 5 Even today, this verse is sung about him:

'Surely no king on earth will follow in Arjuna Kārtavīrya's footsteps, in terms of sacrifices, generosity, austerity, learning or demeanour.' 6 
During his reign, nothing ever decayed and he ruled for eighty-five thousand years with undiminished health, prosperity, energy and courage. 7 One day, Arjuna Kārttavīrya, having had too much to drink, was swimming and relaxing in the waters of the Narmadā River near the city of Māhiṣmatī. Yet he still managed, without effort, to bind Rāvana like a sacrificial animal, and made him stand in a corner of the city, even though Rāvaṇa had begun his conquest of the world and was filled with arrogance after defeating all the deities, Daityas and gandharva lords. 8

At the end of his reign of eighty-five thousand years, Arjuna Kārttavīrya was slain by Paraśurāma, an aspect of Lord Nārāyaṇa. Of his hundred sons, the five most eminent were Sūra, Śūrasena, Vṛṣaṇa, Madhu and Jayadhvaja. 9 Jayadhvaja's son was Tālajangha. Tàlajangha had a hundred sons who were known as the Tălajanghas after him. The eldest one was Vĩtahotra. Another was Bharata. Bharata had two sons, Vṛ̣a and Sujāta. Vṛșa’s son was Madhu. He had one hundred sons of whom Vṛnni was the foremost and after whom the Vṛnni clan is named. 10 They are also known as Madhus after their ancestor of that name, and Yâdavas after Yadu. 11

So ends Chapter Eleven in Book Four of the glorious Viṣnu Purāna.

\section{Yadu's descendant Jyāmagha rescues a princess}

\section{Parāśara:}

Yadu's son Kroșțu had a son, Vṛjinīvant. His son was Svāhi. His son was Rușañku. Ruṣaṅku's son was Citraratha. His son, Śaśabindu, became supreme lord of fourteen great gems. ${ }^{9}$ He had a hundred thousand wives and a million sons, 1 among whom the foremost six were Pṛthuyaśas, Pṛthukarman, Pṛthujaya, Pṛthukīrti, Pṛthudāna and Pṛthuśravas. 2 Pṛthuśravas'sson was Tamas. His son was Uśanas, who performed a hundred horse-sacrifices. His son was called Śitapu. His son was Rukmakavaca. His son was Parāuṛt. Parāvṛt had five sons, named Rukmeșu, Pṛthu, Jyāmagha, Pālita and Harita. 3 These verses about Jyāmagha are still sung today:

'Of all husbands, past or future, who are dominated by their wives, the premier example is King Jyāmagha, Śaibyā’s husband. 4

9 According to the commentary, these are the best discus, chariot, jewel, sword, armour, banner, treasure, wife, family priest, general, charioteer, foot soldiers, horse and elephant. 
Neither he nor Śaibyā had a son, and even though he wanted one, he couldn't take another wife because he feared Śaibyā.' 5

On one occasion, Jyāmagha fought a terrible battle in which hosts of elephants, horses and chariots clashed together. He conquered all his enemy's forces and, abandoning sons, wives, kinsfolk, arms, treasure and territory, they fled in all directions. 6 After they had disappeared, the king beheld a jewel of a royal princess, her almond eyes rolling with fear as she wailed piteously, 'Save me! Save me, Father! Mother! Brother!' 7 As soon as he saw her, the king's heart was filled with affection. 'How excellent is this!' he said to himself, 'I have no children and I'm the husband of a childless wife. Now Fate has provided me with this gem of a girl that I may have progeny. I'll marry her, but first I'll lift her into my chariot and take her to the palace. \& With Queen Śaibyā's permission, she'll become my second wife.' So saying, the king lifted the girl into his chariot and bore her to the capital. 9

Śaibyā came to the palace gate to welcome the victorious king accompanied by all the townsfolk, servants, ministers and attendants. 10 Seeing the girl standing at her husband's left hand, the queen's bud-like lower lip trembled with jealousy. 'You fickle-hearted man!' she said to him, 'Who's this girl riding in your chariot?' The king had no time to consider his reply and, being terrified of his wife, he blurted out, 'She's my daughter-in-law.' 11 Śaibyā replied,

'I've never had a son, and you have no other wife. Which of your sons did this girl marry?' 12

\section{Parāsara:}

Deprived of his better judgement by the queen's harsh words, which were born of jealousy and rage, the king made this reply to avoid any further argument: 'She'll marry the son that you will have one day.' Hearing this, the queen said with a little smile, 'That's all right then', and accompanied the king into the palace. 13

A few days later, at a highly auspicious minute, hour, day and season, as a result of their conversation regarding the birth of a son, and even though she was past childbearing age, Śaibyā conceived an infant. 14 When the time arrived, she was delivered of a boy. His father named him Vidarbha, and he eventually married the girl whom the king had called his daughter-in-law. 15 
Vidarbha had two sons, Kratha and Kaiśika, and later, a third, named Romapāda. Romapāda's son was Babhru. Babhru's son was Dhṛti. Dhṛti’s son was another Kaiśika. Kaiśika's son was Cedi, whose descendants are known as the Caidya kings. Kratha, the son of Jyāmagha's daughter-inlaw, had a son, Kunti. 16 Kunti’s son was Vṛ̣nni. Vṛṣni’s son was Nirvṛti. Nirvṛti's son was Daśārha. His son was Vyoma. His son was Jīmūta. His son was Vikrti. His son was Bhimaratha. His son was Navaratha. His son was Daśaratha. His son was Śakuni. His son was Karambhi. Karambhi's son was Devarāta. His son was Devakșatra. Devakșatra’s son was Madhu. Madhu's son was Anavaratha. Anavaratha's son was Kuruvatsa. His son was Anuratha. His son was Puruhotra. His son was Aṃsu. His son was Satvata. Satvata's descendants are known as the Sātvatas.

One who hears this lineage of Jyāmagha while filled with perfect faith is freed from all misdeeds. 17

So ends Chapter Twelve in Book Four of the glorious Viṣnu Purāna.

\section{Kṛṣna and the Syamantaka jewel}

\section{Parāśara:}

Satvata's sons were Bhajana, Bhajamāna, Divya, Andhaka, Devāvṛdha, Mahābhoja and Vṛ̣ṇi. 1 Bhajamāna's sons with his first wife were Nimi, Kṛkaṇa and another Vṛ̣ṇi, and, with his second wife, Śatajit, Sahasrajit and Ayutajit. 2 Devāvṛdha's son was Babhru. These two verses are sung about them:

'We hear about them when far away and see for ourselves when close at hand: Babhru was first among mankind, and Devāvṛdha was the equal of the gods. 3

One had sixty-six followers, the other six thousand and eight, All of whom won immortality on account of those two alone.' 4

Mahābhoja was deeply religious. His descendants were the Mārtikāvata Bhojas. 5 Vṛ̣ṇi had two sons, Sumitra and Yudhajit. Sumitra's sons were Anamitra and Sinī. Anamitra's son was Nighna. Nighna's sons were Prasena and Satrājita. Lord Āditya, the Sun, was Satrājita's friend. One day, Satrājita was singing the Sun's praises by the ocean, his heart set on that deity alone. While doing so, the Sun appeared before him. Beholding the deity's indistinct form, Satrājita said to him, 'I've seen you resembling a ball 
of fire in the sky, but now you've appeared before me, you haven't blessed me by manifesting clearly.' Hearing this, the lordly Sun took the great jewel known as Syamantaka from around his neck and placed it to one side. 6 Then Satrāita beheld the Sun in a less effulgent form, with reddish eyes that blazed like burnished copper. Satrājita threw himself to the ground and praised the deity, whereupon the Sun offered to grant him anything he desired. Satrājita requested the jewel, the Sun gave it to him and then returned to his station in the heavens. 7

Now the owner of that perfect gem, which he wore around his neck, Satrājita, shining in every direction like the Sun himself, entered Dvārakā. 8 When the residents of the city saw Satrājita approaching, they bowed deeply to Lord Kṛnna, the original being and highest spirit, who had manifested an aspect of himself in human form to relieve the burden of the earth. ${ }^{10}$ 'Lord, surely the Sun has come to see you!' they said. Hearing this, Kṛṣna replied with a laugh, 'This isn't the blessed Sun. It's Saträjita approaching with the great jewel known as Syamantaka, bestowed on him by the deity. You may look upon him fearlessly.' Hearing this, the townsfolk withdrew.

Satrājita kept the great jewel Syamantaka in his own home. 9 Every day, that most magnificent of gems produced eight measures of gold. The power of the jewel also prevented natural disasters throughout the kingdom, including droughts, pests, fires, floods and famines. 10 Infallible Kṛṇa formed the opinion that the jewel would befit his grandfather, King Ugrasena, but fearing this would cause division in his family, he didn't requisition it, even though he could have done so. 11 Satrājita understood that Krṣna desired the jewel and worried that he might request it, so he gave it to his brother Prasena.

Whenever the gem was worn by a man of virtue it brought forth every desirable quality, including rivers of gold, but if the wearer was unvirtuous, the gem would lead to death. This Prasena, wearing the Syamantaka around his neck, went hunting on horseback in the forest, where he was killed by a lion. Having slain both man and horse, the lion then took that perfect gem in his jaws and was about to set off with it, when he was observed by Jāmbavant, the king of bears. Jāmbavant then slew the lion and took the peerless jewel to his cave as a plaything for his son Sukumāra. 12

10 In this chapter, the narrative gets ahead of itself, as here we meet Kṛsna as a mature chieftain in the city of Dvārakā. We will not come to his birth until Chapter 15. For a comprehensive account of the Syamantaka narratives, see Austin (2011). 
When Prasena failed to return, all the Yādavas whispered among themselves, 'Krṣna wants the jewel and Prasena has disappeared. This must be Kṛnna's doing.' 13 When Lord Kṛnna heard these rumours, he set off with the Yādava army. Following the track left by Prasena's horse, he eventually discovered that both horse and rider had been killed by a lion. At the sight of the lion's pawprints, Krṣna was cleared of suspicion by everyone, and continued in search of the culprit. 14 A short distance further he saw where Jāmbavant had killed the lion. Because of the great attraction of the jewel, he now followed the tracks left by the bear. He left the Yâdava soldiers at the foot of the mountain, as he traced Jāmbavant to his lair. Kṛ̣na was halfway into the cavern when he heard the crooning tones of the bear cub's nurse:

'A lion killed Prasena, and Jāmbavant killed the lion. Don't cry little Sukumāra, this Syamantaka is yours.' 15

Hearing this and realising that his goal was within reach, Kṛ̣na entered the cave. There he beheld the Syamantaka, blazing with energy and dangling from the nurse's hand like a bauble for a child. 16 When the nurse saw the stranger approaching with his eager eye on the jewel, she cried, 'Save me! Save me!' 17 Jāmbavant heard her anguished cries and rushed in, his heart filled with fury, whereupon the bear and Kṛ̣na fought a battle for twenty-one days.

The Yâdava soldiers waited for seven or eight days at the foot of the mountain for Kṛṣna to return. When Madhu's adversary failed to reappear, they thought he must have met his match in the cave. How otherwise could it have taken so long for him to overcome his adversary? Returning to Dvārakā, they reported that Kṛ̣na had been killed. 18 His kinsfolk performed all the proper funerary rites and, while Kṛnna kept fighting, the food, water and other substances they offered him in special vessels during the sräddha ritual sustained his strength and vitality. 19 His adversary, Jāmbavant, assailed by that mighty being, his every limb smitten by cruel blows and having nothing to eat, grew weaker by the day.

In the end, the bear surrendered to Lord Kṛṣna and, bowing deeply, said to him, 'You cannot be defeated by gods, demigods, yakșas, gandharvas, rākșasas or any other being, to say nothing of men who walk upon the surface of the earth, who lack courage and have only human limbs to fight with. How much less by an animal like me! You were surely created by our master, Lord Nārāyaṇa, refuge of all the world, as an aspect of himself.' 
Thus addressed by Jāmbavant, Lord Kṛ̣na explained to him in detail that he had appeared to relieve the burden of the earth. Merely with the touch of his hands, Kṛ̣na affectionately dispelled the pain that Jāmbavant suffered during the battle. 20 The bear fell to the ground and, praising Kṛ̣na again and again, presented his daughter, Jāmbavatī by name, as a gift worthy of such a guest. 21 Bowing deeply, Jāmbavant also gave him the Syamantaka jewel. Eternal Kṛṣna accepted the gem from the prostrate beast just to clear his name, even though he had no need to do so. 22 Accompanied by Jāmbavatī, he then returned to Dvārakā.

The residents of the city were filled with joy when Kṛ̣na returned and, seeing him, even those who were stooped with age grew young once more. All the Yâdavas, both men and women, congratulated Kṛ̣ṇa's father, Vasudeva, with the words, 'How fortunate you are! How fortunate!' The lord then explained to all the gathered Yâdavas exactly what had happened. Kṛ̣na returned the Syamantaka to Satrājita and was exonerated of the false accusations that had been made against him. 23 He then conducted Jāmbavatī to the inner chambers.

Satrājita, fearing he had caused a stain on Kṛṣna’s reputation, gave his own daughter Satyabhāmā to him in marriage. She, however, had already been sought by some of the other leading Yàdavas, including Akrūra, Kṛtavarman and Śatadhanvan. Because Satyabhāmā had been given to another, they felt slighted and therefore formed an alliance against Satrājita. 24 Akrūra, Krtavarman and the other leaders said to Śatadhanvan, 'This Satrājita is very wicked. We requested his daughter, as did you, but he ignored us all and gave her to Krṣna. Satrājita's life is worthless. Why don't you kill him and take the jewel? If Kṛ̣na allies himself with Satrājita, we'll come to your defence.' 25 Hearing this, Śatadhanvan accepted their proposal.

Lord Krṣna, who knew the truth about the five sons of Pāndu and the burning house of lacquer, went to Hastināpura, the City of Elephants, in order to placate Duryodhana and to dissuade him from further attempts on the Pāṇdavas's lives. ${ }^{11} 26$ In Kṛṣna’s absence, Śatadhanvan murdered Satrājita while he slept and seized the jewel. Filled with anger at her father's death, Satyabhāmā mounted a chariot and travelled at once to Hastināpura.

11 In the Mahābhārata (1.148), Duryodhana attempted to murder his five Pāṇ̦ava cousins by incinerating them in a house made from flammable lacquer. 
There she said to Kṛnna, 'Śatadhanvan can't accept that I was given to you in marriage. He has killed my father and taken the Syamantaka. Now he's become a laughing stock. Consider this, then do what must be done.' 27

After Satyabhāmā had spoken, Kṛ̣ṇa, although usually kind-hearted, replied to her, his eyes like burnished copper blazed with fury, 'My dear girl, this makes me a laughing stock. I won't stand for this behaviour from that wretch. If you don't fell the tree, you can't kill the birds that nest in it. You've spoken enough of these weighty words, stirred up by grief.' So saying, Kṛ̣na returned to Dvārakā, where he said to Balarāma in secret, 'Prasena was killed by a lion while hunting in the forest. Now Satrājita has been murdered by Śatadhanvan. Because both of them are dead, the jewel should become our property. 28 Get up, mount your chariot and try to kill him.' Balarāma agreed at once and set out in pursuit.

When Śatadhanvan learned that Kṛ̣na and Balarāma had taken up arms against him, he went to Krrtavarman and pressed him for support, but Krtavarman replied that he couldn't fight those two warriors. Hearing this, Śatadhanvan then approached Akrūra, but he gave this reply: 'No-one, even the best of gods who are praised by all the world, would be able to fight Lord Krṣna. His footsteps make the three worlds tremble, he makes widows of the women in the cities of the demigods and he's the discus warrior whose weapon can't be thwarted, even by those of his mightiest foes. Balarāma, the plough-wielding fighter, wild-eyed with drunkenness, destroys his enemy's forces with just a glance. The manifest power of his mighty weapon checks and abolishes even the strongest enemy. What chance have I? Ask someone else to help you.' 29 Hearing this, Śatadhanvan replied, 'If you, knowing your own limits, can't save me, then at least take this jewel and treasure it.' Thus addressed, Akrūra agreed, but added, 'Even under the direst circumstances, you must tell no-one that I have it.' Śatadhanvan agreed and Akrūra accepted the jewel. 30

Śatadhanvan then set off on a mare of unmatched speed that could gallop a hundred leagues a day. But Balarāma and Kṛ̣na followed him in a chariot drawn by four steeds, Śaibya, Sugrīva, Meghapuṣpa and Balāhaka. 31 Śatadhanvan's mare carried him for a hundred leagues, but when they reached the forest regions of Mithilā, the steed expired, so Śatadhanvan abandoned it and set off on foot. 32 Kṛ̣na said to Balarāma, 'You wait in the chariot while I chase this wretch and kill him. The ground here looks too rough for the horses. You won't be able to drive across it.' 33 Balarāma agreed and waited with the chariot, while Kṛṣna chased Śatadhanvan for 
two furlongs. Kṛṣna hurled his discus at his quarry, who was still some way off, and struck off his head. Kṛnna made a thorough search of his victim's body, clothes and possessions but failed to find the Syamantaka. Returning to Balarāma, he said, 'We've killed Śatadhanvan for nothing, as I still haven't found the jewel, the essence of the world.'

Hearing this, furious Balarāma cursed Vāsudeva, 'Damn you! You hanker after wealth so much, I can't bear to be your brother! My path lies here, you can go where you like. I'll have nothing more to do with Dvārakā or the rest of the family. I've had enough of the deceitful curses you've made in my presence.' Even though Kṛnna had been reviled with these words, he tried to placate Balarāma, but his brother, refusing to stay, took refuge in the city of Videha. 34 There, King Janaka welcomed him hospitably and showed him to the palace, where he remained. Vāsudeva, however, returned to Dvārakā. While Balarāma lived in King Janaka's domain, he personally instructed Dhṛtarāstrta's son Duryodhana in how to wield the mace. Three years later, Babhru, Ugrasena and other Yâdava clansmen, realising that Kṛ̣na hadn't seized the gem, went to Videha to convince Balarāma to return with them to Dvārakā. 35

Akrūra, however, was obsessed with the thought of the gold brought forth by that extraordinary jewel. He undertook many sacrifices because he knew that killing a kṣatriya or a vaiśya who is engaged in such a rite is tantamount to brahminicide. He was therefore able to protect himself by maintaining his sacrificial initiation. For sixty-two years, owing to the power of the jewel, the kingdom was free from calamity, famine and epidemics. 36 Later, when Sātvata's great-grandson Śatrughna was killed by the Bhojas allied with Akrūra, they all abandoned Dvārakā and fled together. 37 From the very day they departed, disasters, wild animals, drought, plague and other troubles struck. Lord Kṛ̣na, who has Garuḍa, the enemy of serpents, on his banner, then summoned the Yâdavas along with Balarāma and Ugrasena to ask them why so many calamities had befallen at the same time. 38 After Kṛ̣ṇa had spoken, a Yādava elder named Andhaka gave this explanation:

'Wherever Akrūra's father, Śvaphalka, ventured, such places were free from famine, plague, drought and other woes. 39 Śvaphalka was invited to the king of Kāssîs's realm during a particularly long drought, and at once the rains began to fall from heaven. The consort of the king had earlier conceived a baby girl, 40 but on the date it was due, no infant was delivered. Indeed, twelve years passed and still the child remained unborn. The king of Kāśi then addressed his daughter in the womb, "Why aren't 
you born? Come out! I want to see your face. Why do you make your mother suffer so?" Hearing this, the infant in the womb replied, "Father, if you give the brahmins one cow every day, I'll surely leave this womb in three years' time." Hearing this, the king did as she suggested, and the baby girl was duly born three years later. Her father named her Gāndinī, and later bestowed her on Śvaphalka as a gift befitting a guest who'd shown the king such kindness. ${ }_{11}$ Śvaphalka and Gāndinī had a son, Akrūra. As such, Akrūra's birth was the result of the union of excellent qualities. 42 Now that he has gone, how could there be no pestilence, famine or other calamities? You must therefore beg him to return. What's the use of finding fault in a person of such virtues?' 43

Hearing this report from the Yadu elder Andhaka, the Yãdavas, led by Keśava, Ugrasena and Balarāma, gave Śvaphalka's son Akrūra a guarantee that they would overlook the offences he'd committed and invited him to return to the city. As soon as Akrūra came back, drought, plague, famine, pests and other troubles all abated owing to the power of the gem he wore.

'The fact that Akrūra was born to Gāndinī and Śvaphalka is irrelevant,' thought Kṛ̣na. 'Only a greater power could prevent such troubles. 44 He surely has the mighty Syamantaka about his person, as people say it has the power to do such things. Akrūra has been undertaking one sacrifice after another, but I doubt he can afford to do so. It's clear he has the jewel.'

Reaching this conclusion, Kṛ̣na found a pretext to call a meeting of all the Yādavas in his residence. 45 When they were seated, Janārdana revealed his true intent and, having done so, gave an amusing speech for Akrūra, befitting the occasion, in which he said to him, 46 'You're a wealthy man, and we know that Śatadhanvan gave Syamantaka, the essence of all the world, to you. This jewel, which profits the entire kingdom, is in your possession. Leave it with us, so we may all benefit from its power. Balarāma, however, suspects that I have it, so do us all a favour and reveal it.'

Hearing this, Akrūra, who did indeed possess the gem, said to himself, 47 'What's to be done now? If I deny I have the jewel, they'll search for it and, as it's hidden in my clothes, they'll certainly discover it.' With this thought, Akrūra decided to avoid a search and said to Kṛnna -Nārāyaṇa, cause of all the universe, 'Lord, Śatadhanvan gave me this Syamantaka jewel. 48 Ever since he left, I always thought that you'd ask me for it - if not today, then tomorrow or the following day. Because of the burden of wearing it, I've lost all interest in pleasures, nor do I have a moment's happiness. 49 
All this time, I've feared you'd think I couldn't bear the jewel that benefits this whole realm, so I said nothing. 50 Take the Syamantaka and give it to whomsoever you desire.'

Akrūra then produced a tiny golden casket from beneath his dhoti; 51 taking out the Syamantaka, he set it before the Yâdava assembly. As soon as he had done so, a lovely light spread in all directions. 52 Akrūra continued, 'Here's the jewel that Satadhanvan gave me. Let its rightful owner take it.' Seeing the gemstone, all the astonished Yàdavas cried out, 'Marvellous! Marvellous!' When Balarāma beheld the stone, he was filled with greed and said to himself, 'It's mine! Never-failing Kṛṣna and I searched for it together.' 53 Satyabhāmā also wanted it, as she considered it the property of her father, Satrājita.

Seeing Balarāma's and Satyabhāmā’s faces, Kṛṣna felt like an ox yoked to two wagons. In the presence of all the Yàdavas, he said to Akrūra, 'By showing this jewel in the presence of the assembly, my name's been cleared. It's owned in common by me and Balarāma, but it's also part of Satyabhāmā's patrimony. It belongs to no-one else. 54 When the jewel is carried at all times by a person, pure and chaste, who adheres to virtue, it benefits the realm, but if it's carried by an unchaste man, the jewel will be his downfall. 55 I have sixteen thousand wives, so I'm not qualified to carry it. How could Satyabhāmā accept it either? Noble Balarāma has succumbed to drink and other pleasures, so he can't have it. For these reasons, this whole Yadu clan, including Balarāma, Satyabhāmā and myself, beseech you, Akrūra, a wealthy man, as you alone are fit to bear the jewel. In your possession, it will benefit the entire realm. You, therefore, should carry it as before, since it brings prosperity to the land. Please don't try to argue with us!' Hearing this, munificent Akrūra agreed to accept the mighty gem and, from that day, he wore it openly and moved about like the light-wreathed sun, shining with the extraordinary brilliance of the jewel that hung about his neck. 56

Anyone who recalls how Lord Kṛnna was absolved of this false accusation will not suffer even the slightest allegation himself, his senses will never be impaired and he'll be absolved of all his sins. 57

So ends Chapter Thirteen in Book Four of the glorious Viṣnu Purāna. 


\section{The ancestry of Kṛ̣nạ’s father, Vasudeva, and his nemesis, Śiśupāla}

\section{Parāśara:}

Anamitra's son was Śini. ${ }^{12}$ His son was Satyaka. Satyaka's son was Sātyaki, also known as Yuyudhāna. His son was Asangga. His son was Tūṇi. Tūṇi’s son was Yugamdhara. These were known collectively as the Śaineyas. I Vṛ̣ṇi was born in the lineage of Anamitra. His son was Śvaphalka, whose prowess has already been described. Śvaphalka's younger brother was called Citraka. Śvaphalka and Gāndinī’s son was Akrūra. Their other son was Upamadgu. Upamadgu's sons were Mṛdura, Viśāri, Mejaya, Girikṣatra, Upakṣatra, Śatrughna, Arimardana, Dharmadṛk, Dṛsțavarman, Gandhamojavāha and Prativāha. They also had a daughter named Sutārā. Akrūra had two sons, Devavant and Upadeva.

Citraka had many sons, among whom Prthu and Viprthu were the foremost. 2 Andhaka had four sons, Kukura, Bhajamāna, Śuci and Kambalabarhis. 3 Kukura's son was Dhṛța. His son was Kapotaroman. His son was Viloman. His son was Bhava, also known as Candanodaka Dundubhi, a friend of the gandharva Tumburu. His son was Abhijit. His son was Punarvasu. He had a son, Āhuka, and a daughter, Āhukī. 4 Āhuka had two sons, Devaka and Ugrasena. Devaka had four sons, Devavant, Upadeva, Sudeva and Devarakṣita. They had seven sisters, Vṛkadevā, Upadevā, Devarakṣitā, Śrīdevā, Śāntidevā, Sahadevā and Devakī-all of whom were married to Vasudeva.

Ugrasena's sons were called Kaṃsa, Nyagrodha, Sunāman, Kan̉ka, Śan̉ku, Subhūmi, Rāṣṭrapāla, Yuddhamuștị and Tușțimant. Ugrasena’s daughters were Kaṃsā, Kaṃsavatī, Sutanu, Rāștrapālī and Kanikī. Bhajamāna’s son was Vidūratha. Vidūratha's son was Śūra. Śūra's son was Śamin. Śamin's son was Pratikșatra. His son was Svayambhoja. His son was Hṛdika. 5 His sons were called Kṛtavarman, Śatadhanu and Devamị̣̂huṣa. 6 Devamị̣̄huṣa's son, Śūra, had a wife named Mārișā. 7 They had ten sons, of whom Vasudeva was the first. As soon as Vasudeva was born, the deities, who could see the future clearly, realised that he was an aspect of Lord Viṣnu manifesting in the world, and caused divine anaka and dundubbi drums to be beaten throughout the royal residence. That's why he was given the

12 Elsewhere, Śini (or Śinī) is said to be Anamitra's younger brother (4.13.6 above). In any case, Anamitra was the grandfather of Satrājita, who featured in the Syamantaka narrative above. 
name Ānakadundubhi at the time. Vasudeva had nine brothers: Devabhāga, Devaśravas, Anādhṛștị, Karundhaka, Vatsabālaka, Srñnjaya, Śyāma, Śamīka and Gaṇdūsạ. His five sisters were Pṛthā, Śrutadevā, Śrutakīrti, Śrutaśravas and Rājādhidevī. 8

Sunra had a friend by the name of Kunti who had no children, so he duly gave Kunti his own daughter, Pṛthā. She was married to Pāṇụu. Pṛthā conceived three sons, Yudhișthira, Bhīma and Arjuna, with the deities Dharma, Vãyu and mighty Indra, respectively. Earlier, as a young, unmarried woman, she had a son by the name of Karṇa with the lordly Sun. 9 Pṛthā's co-wife Mādrī bore two more sons for Pāṇụ, Nakula and Sahadeva, with the divine Aśvins, Nāsatya and Dasra. ${ }^{13}$

Vasudeva's sister Śrutadevā was married to Vṛddhaśarman, a prince of the Kārūṣas. Their son was the great demigod Dantavakra. Śrutakīrti was married to the king of the Kaikeyas. They had five sons, including Samtardana, who were also known as Kaikeyas. Rajjādhidevī bore the two Avantis, Vinda and Anuvinda. Śrutaśravas was married to Damaghoṣa, the king of the Cedis. She bore Śiśupāla.

In a previous life, Śiśupāla had been the unruly but courageous Daitya king Hiranyakaśipu, 10 who was slain by Lord Viṣnu, preceptor of all the world. Hiranyakaśipu was reborn as the ten-headed Ràvana, whose qualities of energy, valour, accomplishment and prowess were unrivalled, and who conquered the three worlds with his regal might. 11 Because Ravvana had been in the presence of the lord so long, and as a result of the merit he acquired in bodily form, he was killed by Lord Viṣnu in the person of Rāma, descendant of Raghu. Rāvana was then reborn as the overlord of the Cedis, Siśupāla by name, the son of the Cedi king Damaghoṣa. 12 Appearing in this form, he was even more hostile towards Lord Viṣnu, who had manifested an aspect of himself in the world as lotus-eyed Kṛ̣na to ease the burden of the earth. Siśupāla was slain by the lord, but even so, as his mind had been fully focused on the supreme spirit, he achieved a state of union with the divine. 13 When the lord is pleased, he grants all wishes. Even when displeased, to the extent of striking down an enemy, he may still bestow peerless divinity upon that being. 14

So ends Chapter Fourteen in Book Four of the glorious Viṣnu Purāna. 


\section{Hiraṇyakaśipu, Rāvaṇa and Śiśupāla}

\section{Maitreya:}

In the persons of Hiranyakaśipu and Rāvaṇa, that being, slain by Viṣnu, achieved an everlasting state of bliss that lies even beyond the reach of gods. 1 How, then, did he achieve this state of union with eternal Hari when slain again in the person of Siśupāla? 2 I wish to hear about this, as you're preeminent among those who uphold virtue. I ask because I'm filled with curiosity, and it befits you to explain all this to me. 3

\section{Parāśara:}

In former times, the lord, who is the cause of creation, preservation and destruction of the world, manifested in physical form as the man-lion Nrssiṃha to kill the Daitya king. Hiranyakaśipu, however, had no inkling that his adversary was Viṣnu. 4 A single thought arising from excessive passion occupied his mind: that his state of excellence was born of the peerless merit that he acquired. As a result of this conception, after he was slain by Viṣnu, he achieved unchallenged sovereignty in all three worlds in the person of ten-headed Rāvana, winning leisure and prosperity. 5

Even then, his mind did not achieve absorption with Lord Viṣnu, the highest Absolute, who has neither start nor finish and needs no other support. Again, in the person of Rāvanaa, obsessed with the thought of love, he set his heart on Janaka's daughter Sītā. When he saw Viṣnu, who'd taken the form of Rāma, the son of Daśaratha, he failed again to recognise the eternal lord. Even at the moment of his death, he mistook his slayer for a mortal. 6 Just by being slain by Viṣnu, he won rebirth and sovereignty in the world-renowned line of Cedi kings in the person of Śiśupāla. 7 His heart constricted by an enmity that grew stronger over many lifetimes, when mocking or abusing Viṣnu, Śiśupāla constantly uttered every name of the everlasting deity, all of which affected him. 8 As a consequence of his deep hostility, whether walking, eating, bathing, sitting, reclining or anything else, the image of Viṣnu never left his mind: eyes like the unstained petals of a full-blown lotus, clad in radiant golden garments, resplendent with gleaming diadem, armbands and bracelets, and sporting four long, strong arms that held the discus, conch and mace. 9

Calling his name, and holding him ever in his thoughts, Śiśupāla beheld Lord Kṛșna in the form of indestructible energy, the supreme Absolute, blazing with rays of light that shone from his heavenly discus, which was 
destined for his demise. Śiśupāla was freed from passion, anger and every other fault. 10 The instant that the lordly discus struck him, recalling the Divine, all his sins were burned away and, even though he was slain by Kṛṣna, he achieved absorption into him.

Now I've explained it all to you: when the lord is called by name or contemplated, even by a person bound by hatred, he bestows rewards that even gods or demigods or any other being find hard to win. How much greater the reward, then, for those who are filled with perfect faith?

\section{The descendants of Vasudeva and Kṛ̣na}

Kṛ̣na’'s natural father, Vasudeva, also known as Ānakadundubhi, had many wives, the foremost being Pauravī, Rohin̄ī, Madirā, Bhadrā and Devakī. 11 Ānakadundubhi's sons with Rohiṇī included Balarāma, Sāraṇa, Śaṭha and Durmada. Balarāma had two sons with Revatī, Niśatha and Ulmuka. The foremost sons of Sāraṇa were Mārșți, Mārșimant, Śiśi, Śiśu and Satyadhṛti. Bhadrāśva, Bhadrabāhu, Durdama, Bhūta and others were also born in the family of Rohin̄i. 12 Vasudeva's sons with Madirā included Nanda, Upananda and Kṛtaka. With Bhadrā, he fathered Upanidhi, Gada and others. With Vaišâlī, he had one son, Kauśika. Ānakadundubhi had six sons with Devakī, named Kīrtimant, Sușeṇa, Udāyin, Bhadrasena, R.judāsa and Bhadradeva, 13 all of whom were killed by Kamsa. Following this, the lord sent Yoganidrā to take the seventh infant from Devakì's womb in the middle of the night and place it in Rohinī's. 14 Because he'd been pulled (karșañat) from the womb, this child, Balarāma, was also known as Saṃkarṣaṇa. 15

Next, Lord Vāsudeva-root of the spreading universal tree; who lies beyond the conception of all the gods, demigods, sages and humans of the past, the present and future; who is worshipped by reverent deities led by lotus-born Brahmā and by the elements led by Fire; and who has neither start nor middle-descended to the womb of Devaki to ease the burden of the earth. 16 Yoganidrā, whose pride and love had burgeoned through the blessings of the lord, carried the infant Vāsudeva to the womb of Yaśodā, wife of cattle-herding Nanda. 17

When lotus-eyed Kṛnna was born, the sun, moon and planets shone more brightly, fear of wild animals subsided, minds were eased and in every corner of the world immoral conduct was set aside. 18 At his birth, all the world was led to the path of righteousness. The lord, having descended to the mortal world, took sixteen thousand, one hundred wives. Among these, eight consorts were foremost, including Rukmiṇī, Satyabhāmā, Jāmbavatī and 
Cāruhāsinī. With these women, the lord, whose form is universal and has no beginning, sired one hundred and eighty thousand sons. 19 The thirteen most important included Pradyumna, Cārudeșna, Sāmba and others. Pradyumna married Rukmin's daughter Kakudvatī, and they had a son, Aniruddha. Aniruddha married Rukmin's granddaughter Subhadrā, and they had a son, Vajra. Vajra's son was Pratibāhu, and his son was Sucāru.

It would be impossible, even in many centuries, to know all the members of the Yadu clan, who numbered in the hundreds of thousands. Two songs in praise of them are current: 20

'Thirty-eight million inhouse instructors happily taught archery to the youths of the mighty Yâdava clan. 21 Who, then, could put an exact number to the family of ten thousand times ten thousand times one hundred thousand souls, among whom the king, Āhuka, is always present?' 22

'The mighty Daityas, struck down in battle with the gods, were born again as tyrants among mankind. 23 The deities appeared on earth to vanquish them, brahmin, as the one hundred and one branches of the Yadu clan.' 24

Viṣnu was established as their paragon and overlord, and the Yâdavas all obeyed his word. 25

Anyone who listens repeatedly to the origins of the Vṛ̣ni heroes is freed from all misdeeds and will reach the realm of Viṣnu. 26

So ends Chapter Fifteen in Book Four of the glorious Viṣnu Purāna.

\section{Yayāti's son Turvasu}

\section{Parāsara:}

I've described in brief the lineage of Yadu. Now you'll hear about Turvasu's descendants. His son was Vahni. Vahni's son was Gobhānu. His son was Traiśānu. His son was Karaṃdhama. His son was Marutta. Marutta had no sons of his own, so he adopted Dusyanta, the Puru's descendant. In this way, as the result of Yayāti's curse, the lineage of Turvasu had to merge with that of Puru. ${ }^{14} 1$

\section{So ends Chapter Sixteen in Book Four of the glorious Viṣnu Purāna.}

14 Turvasu refused to exchange his youthfulness for Yayāti's old age, so Yayāti cursed him so that he would never wield sovereignty. See above, 4.10.8. In this passage, the text uses Pūru for Puru. I have standardised on the latter. 


\section{Yayāti’s son Druhyu}

\section{Parāśara:}

Druhyu's son was Babhru. 1 His son was Setu. His son was called Āradvant. His son was Gāndhāra. His son was Dharma. His son was Dhṛta. Dhṛta's son was Durdama. His son was Pracetas. Pracetas had one hundred sons who became overlords of the heretical barbarians of the north. 2

So ends Chapter Seventeen in Book Four of the glorious Viṣnu Purāna.

\section{Yayāti’s son Anu}

\section{Parāśara:}

Yayāti’s fourth son, Anu, had three sons: Sabhānara, Cakșu and Paramekṣu. Sabhānara’s son was Kālānara. Kālānara's son was Sṛñjaya. Sṛñjaya’s son was Puramjaya. His son was Janamejaya. His son was Mahāśāla, and his son was Mahāmanas. His two sons were Uśinara and Titikșu. Uśĩnara had five sons: Śibi, Nrga, Nara, Kṛmi and Darva. Śibi had four sons: Vṛsadarbha, Suvīra, Kaikeya and Madraka. Titikșu's son was Ruṣadratha. His son was Hema. Hema's son was Sutapas. His son was Bali. With Bali's wife, Dīrghatamas had Anga, Vanga, Kalinga, Suhya and Pauṇ̣̂ra—the Bāleya warriors. 1 Each of their lineages was named after them, as were their five kingdoms. Anga's son was Anapāna. His son was Diviratha. His son was Dharmaratha. His son was Citraratha, also known as Romapāda. His son was Daśaratha. As this Daśaratha was childless, Aja's son, also named Daśaratha, gave him his daughter Śāntā. 2 Romapāda's son was Caturanga. His son was Pṛthulākșa. His son was Campa, who founded the city of Campā. 3 Campa's son was Haryanga. His son was Bhadraratha. His son was Bṛhadratha. His son was Bṛhatkarman. Bṛhatkarman’s son was Bṛhadbhānu. His son was Brhanmanas. His son was Jayadratha, who married the daughter of a brahmin mother and a kșatriya father. Together they had a son named Vijaya. 4 Vijaya's son was Dhṛti. His son was Dhṛtivrata. Dhṛtivrata's son was Satyakarman. Satyakarman's son was Adhiratha. It was he who, wandering along the banks of the Gangā, found Karna in a basket where 
he had been abandoned by his mother, Pṛthā. Adhiratha adopted Karṇa as his own son. ${ }^{15}$ Karna's son was Vrșasena. These were the descendants of Anga. 5 Next you'll hear about the lineage of Puru. 6

So ends Chapter Eighteen in Book Four of the glorious Viṣnu Purāna.

\section{Yayāti’s son Puru}

\section{Parāśara:}

Puru's son was Janamejaya. His son was Pracinvant. Pracinvant's son was Pravīra. His son was Manasyu. Manasyu's son was Abhayada. His son was Sudyu. Sudyu's son was Bahugava. His son was Samyāti. Samyāti's son was Ahamyāti. His son was Raudrāśva. Raudrāśva had ten sons, named Ṛteyu, Kakṣeyu, Sthaṇdileyu, Dhṛteyu, Jaleyu, Sthaleyu, Dharmeyu, Sannateyu, Dhaneyu and Vaneyu.

R.teyu's son was Rantināra. Rantināra’s sons were Sumati, Apratiratha and Dhruva. Apratiratha's son was Kaṇva. His son was Medhātithi, from whom the Kānnvāyana brahmins were descended. Apratiratha's other son was Ailinna. He had four sons, the eldest of whom was Dusyanta. Dusyanta's son was the universal sovereign Bharata. The deities sang this verse to explain his name:

'A mother is but a pouch of skin. The son is indeed his father's, as he is the begetter. Dusyanta, cherish (bharasva) your son, and don't belittle Śakuntalā. 1

The son, as the bearer of semen, saves his forefathers from destruction wreaked by Yama. You're the maker of this embryo and Śakuntala spoke the truth, your majesty. ${ }^{{ }^{16}} 2$

Bharata had nine sons with his three wives, but because the sons didn't resemble him, their own mothers killed them fearing that Bharata would reject them. No further sons were born to him, but as he still yearned for progeny, he performed a soma sacrifice to the Maruts, the wind gods. When Dìrghatamas was still a foetus in the womb, he kicked out Bṛhaspati's sperm. The Maruts therefore gave Bharata a son, Bharadvāja, with Mammatā, the wife of Utathya. 3 This verse is sung to explain the origin of his name: 4

15 Karna was one of the great warrior heroes of the Mahäbhärata.

16 Mahābhārata, 1.90.30-33. These characters are at the heart of Kālidāsa's great drama,

Abbijñānaśākuntala. 
'Foolish woman, take care of (bhara) this child born of two fathers (dvajjam).' 'No, Brihaspati, you take care of him!' So saying, both parents left. That's how Bharadvāja got his name. 5

Because Bharata's desire for the birth of a son had been in vain (vitatha), Bharadvāja, who had been given to him by the Maruts, was also called Vitatha. 6 Vitatha's son was Bhavanmanyu. The sons of Bhavanmanyu were Bṛhatkṣatra, Mahāvīrya, Nara and Garga. Nara’s son was Samkṛti. Saṃkṛti's sons were Ruciradhī and Rantideva. Garga's son was Śini. Their descendants, known as Gārgyas and Śainyas, were kṣatriyas by birth but later became brahmins. 7 Mahāvīrya had a son called Durukșaya. He had three sons, Trayyāruna, Puṣkarin and Kapi, the last of whom also became a brahmin at a later date. Brihatkșatra's son was Suhotra. Suhotra's son was Hastin, who founded the city of Hastināpura. The three sons of Hastin were Ajamị̣̂ha, Dvimīẹha and Purumị̄ha.

Ajamīẹha’s first son was Kaṇva. Kaṇva’s son was Medhātithi, from whom the Kānvāyana brahmins were descended. \& Ajamịnha's other son was Bṛhadișu. His son was Bṛhaddhanu. His son was Bṛhatkarman. His son was Jayadratha. His son was Viśvajit. His son was Senajit. Senajit's sons were called Rucirāśva, Kāśya, Dṛ̣hahanu and Vatsahanu. Rucirāśva’s son was Pṛthusena. His son was Pāra. Pāra’s son was Nīpa. He had a hundred sons, among whom the foremost was Samara, king of Kāmpilya. 9 Samara had three sons, Pāra, Supāra and Sadaśva. Pāra’s son was Pṛthu. Pṛthu's son was Sukṛti. Sukṛti's son was Vibhrāja. His son was Aṇuha, who married Śuka's daughter Kṛtvī. 10 Aṇuha’s son was Brahmadatta. His son was Viṣvaksena. His son was Udaksena. His son was Bhallāța.

Dvimīẹha's son was called Yavinnara. His son was Dhṛtimant. His son was Satyadhrti. His son was Dṛ̣hanemi. His son was Supārśva. His son was Sumati. His son was Sannatimant. Sannatimant's son was Krrta, to whom Hiranyanābha taught yoga, and who created twenty-four compendiums for brahmins in the east who sang the Säma Veda. 11 Kṛta's son was Ugrāyudha, by whom the Nippa clan of kșatriyas was almost annihilated. 12 Ugrāyudha’s son was Kșemya. Kșemya’s son was Suvīra. His son was Ripumjaya. His son was Bahuratha. Such were the descendants of Puru, the Pauravas.

Ajamị̣ha's wife was named Nalinī and they had a son called Nīla. His son was Śānti. Śānti’s son was Suśānti. Suśānti’s son was Purujānu. His son was Cakșus. His son was Haryaśva. Haryaśva’s sons were Mudgala, Sṛñjaya, Bṛhadiṣu, Pravīra and Kāmpilya. Their father said, 'My five (pañca) sons are 
able (alam) to protect their dominions', hence their epithet, the Pāñaalas. 13 From Mudgala were descended the Maudgalyas, who were born kṣatriyas but later became brahmins. Mudgala's son was Vadhyaśva. Vadhyaśva had twins, a son, Divodāsa, and a daughter, Ahalyā. With Ahalyā, Śaradvat had a son, Śatānanda. Śatānanda's son was Satyadhṛti, who attained perfect knowledge of archery. While spying on the exquisite apsaras Urvaśí, Satyadhrti ejaculated into a clump of grass. The clump split in half and brought forth two infants, a boy and a girl. One day, King Śāmtanu was out hunting when he came upon the children and, feeling compassionate $(k r p \bar{a})$, he took them in. Accordingly, the boy was named Krpa, and the girl, Kṛpī. She later married Droṇa and was Aśvatthāman’s mother.

Divodāsa's son was Mitrāyu. Mitrāyu's son was the king called Cyavana. Cyavana's son was Sudāsa. His son was Saudāsa Sahadeva. His son was Somaka. He had one hundred sons, of whom Jantu was the eldest and Pṛșata the youngest. Pṛșata’s son was Drupada. His son was Dhṛștadyumna. His son was Dhṛțtaketu.

Ajamịtha had another son by the name of Ṛkṣa. Ṛkṣa's son was Samvaraṇa. Samvarana's son was Kuru, who created the sacred plain of Kurukșetra. The preeminent sons of Kuru were Sudhanus, Jahnu and Parikṣit. Sudhanus's son was Suhotra. His son was Cyavana. Cyavana's son was Krtaka. His son Uparicara was also known as Vasu. Vasu had seven sons led by Bṛhadratha, Pratyagra, Kuśāmba, Māvella and Matsya. Bṛhadratha's son was Kuśāgra. His son was R.̣abha. His son was Puṣpavant. His son was Satyahita. His son was Sudhanvan. His son was Jantu. Brihadratha had another son who was born in two halves. These were joined together (samdhita) by a rākṣasī named Jarā. That's why he was called Jarāsandha, 'Joined by Jarā'. His son was Sahadeva. His son was Somapi. His son was Śrutaśravas. Such were the kings of Magadha. 14

So ends Chapter Nineteen in Book Four of the glorious Viṣnu Purāna.

\section{The lineages of the Kauravas and Pạnḍavas}

\section{The glorious Parāiara:}

Parīkṣit had four sons: Janamejaya, Śrutasena, Ugrasena and Bhīmasena. 1 Janhu Janamejaya had a son named Suratha. 2 His son was Vidūratha. Vidūratha's son was Sārvabhauma. Sārvabhauma’s son was Jayasena. His son was Ārādhita. His son was Ayutāyu. Ayutāyu's son was Akrodhana. 
His son was Devātithi. His son was R kṣa. 3 R ksṣa’s son was Bhīmasena. His son was Dilīpa. Dilīpa's son was Pratīpa. He had three sons, called Devāpi, Śāṃtanu and Bāhlīka. Devāpi retired to the forest while still a child 4 so Sāṃtanu became the king. In all the world, they sing this verse about him:

'Each old man he touches with his hands grows young again and discovers perfect peace (s'änti). That's why he's called Śāṃtanu.' 5

No rain fell in Śāmtanu's kingdom for twelve years. 6 Seeing the destruction of his entire realm, the king asked the brahmins, 'What's caused this drought in our kingdom? What have I done wrong?' They replied, 'You're enjoying this earth, which really belongs to your elder brother, as you married before he did.' Hearing this, the king asked them what he should do. They replied, 'As long as Devāpi doesn't surrender to faults such as heresy, he'll remain fit to rule. You should therefore abdicate in his favour.' At this, the chief minister, Aśmasārin, made contact with some ascetics in that same forest who taught doctrines contrary to Vedic tradition. 7 These ascetics then set that honest prince's mind on a path that led away from the Vedas. 8

King Saamtanu, smarting at the criticism of his early marriage, sent the brahmins to the forest ahead of him, then proceeded there himself to confer the kingdom on his elder brother. On reaching Devāpi's ashram, they all assembled before the prince. The brahmins then explained to Devāpi that Vedic doctrine required the first-born son to rule the kingdom. Devāpi, however, offered them many rejoinders, but his reasoning was rife with ideas that ran counter to the Vedas. The brahmins then said to Śāmtanu, 'Come, your majesty. There's no point in persisting with this. The drought will soon be over. This man is an apostate who disparages the timeless Vedic teachings. When an older brother has fallen, it's not unlawful for his younger brother to marry first.' Hearing this, Śāṃtanu returned to the capital and ruled the kingdom. As soon as Devāpi was compromised by uttering words that were inconsistent with the Vedas, the rain god, Parjanya, sent down showers to nourish all the crops.

Bāhlīka's son was Somadatta. 9 Somadatta had three sons, named Bhūri, Bhūriśravas and Śalya. Śāṃtanu's son with the river goddess Gangā was Bhissma of noble repute, who understood the import of all the scriptures. Sāmẹtanu also had two sons with Satyavatī, Citrāngada and Vicitravīrya. Citrāngada was killed while young in battle with a gandharva who had the same name as himself. Vicitravirya married two daughters of the king of Kāsî̀, Ambikā and Ambālikā. He wore himself out while enjoying intercourse with them, contracted consumption and died. At the direction of Satyavatī, her son Kṛ̣ṇa-Dvaipāyana, believing that a mother's word 
must never be disobeyed, had two sons with Vivitravīrya's widow—namely, Dhṛtrāṣțra and Pāṇ̣u. He had another son, Vidura, with a serving-girl who had been thrust upon him. 10

Dhṛtarāsțra had a hundred sons, among the foremost of whom were Duryodhana and Duhśāasana. Pānḍu was unable to sire children himself because he had been cursed by a deer in the forest. His senior wife Kuntī consequently conceived Yudhișthira, Bhìma and Arjuna with the deities Dharma, Vāyu and Indra, while his younger wife Mādrī conceived Nakula and Sahadeva with the Aśvins, giving Pāndu five sons in all. These five each had a son with Draupadī: Yudhișthira had Prativindhya, Bhīmasena had Śrutasoma, Arjuna had Śrutakīrti, Nakula had Śatānika and Sahadeva had Śrutakarman.

The Pāṇavas also had other sons, as follows: Yudhișthira had a son, Devaka, with Yaudheyī. Bhīmasena had a son, Ghațotkaca, with Hidimbā. Bhīmasena had a son, Sarvatraga, with Kāsíi. Sahadeva had a son with Vijayā, named Suhotra. Nakula had a son, Niramitra, with Karenamatī. 11 Arjuna had a son named Irāvant with Ulūpī, the nāga's daughter. With the daughter of the king of Manipura, Arjuna had a son named Babhruvāhana, whom his maternal grandfather adopted as his own son. 12 With Subhadrā, Arjuna had a son, Abhimanyu, who, with his great strength and prowess, destroyed all his enemies' chariots even though he was just a lad. Abhimanyu and Uttarā had a son, Parikssit, who, while still in the womb, was burned to ashes by the Brahmāstra weapon loosed by Aśvatthāman after all the Kurus had been annihilated. Parîkșit was restored to life through the intercession of Lord Kṛnna, whose feet are worshipped by every god and demigod and who took human form of his own volition. It is Parikssit who rules all the world today in accord with virtue. 13

So ends Chapter Twenty in Book Four of the glorious Viṣnu Purāna.

\section{The future descendants of Parīkșit}

\section{Parāśara:}

I'll now name the kings who will appear in future. The current sovereign, Parikssit, will have four sons, Janamejaya, Śrutasena, Ugrasena and Bhīmasena. 1 Parīkṣit's other son, Śatānīka, will study the Vedas under Yājñavalkya. He'll then obtain weapons from Kṛpa but will be disillusioned with worldly pleasures. Under the guidance of Śaunaka, he'llgain knowledge of the Self and will eventually achieve final liberation. 2 Śatānikka's son will 
be Aśvamedhadatta. His son will be Adhisīmakṛṣna. Adhisīmakṛṣna’s son will be Niścaknu, who'll reside in Kauśambī when Hastināpura is washed away by the Gangā. His son will be Uṣna. Uṣṇa's son will be Citraratha. His son will be Śuciratha. His son will be Vṛ̣nimant. His son will be Sușeṇa. His son will be Sunītha. Sunītha's son will be Rca. His son will be Nrrcakșus. His son will be Sukhibala. His son will be Pariplava. His son will be Sunaya. His son will be Medhāvin. His son will be Nṛpamjaya. His son will be Mrrdu. His son will be Tigma. Tigma’s son will be Bṛhadratha. His son will be Vasudāna. His son will be another Śatānīka, and his son will be Udayana. Udayana's son will be Ahīnara. His son will be Daṇdapāṇi. His son will be Niramitra, and his son will be Kșemaka, about whom there is a verse:

'The lineage, which was the origin of the brahmins and kṣatriyas, and was honoured by sagacious kings, will come to an end in the age of Kali with the king named Kșemaka.' 3

So ends Chapter Twenty-One in Book Four of the glorious Viṣnu Purāna.

\section{The future descendants of Brhadbala}

\section{Parāśara:}

Now I'll name the future kings in the lineage of Ikṣvāku. Bṛhadbala's son will be Bṛhatkșana. ${ }^{17} 1$ His son will be Urukșaya. His son will be Vatsa. Vatsa's son will be Vatsavyūha. His son will be Prativyoma. His son will be Divākara. His son will be Sahadeva. 2 His son will be Bṛhadaśva. His son will be Bhānuratha. His son will be Pratītāśva. His son will be Supratīka. His son will be Marudeva. Marudeva's son will be Sunaksatra. His son will be Kimnara. Kimnara's son will be Antarikșa. His son will be Suvarna, and his son will be Amitrajit. His son will be Bṛhadrāja. His son will be Dharmin. Dharmin's son will be Kṛtamjaya. Kṛtamjaya’s son will be Raṇaṃjaya. Ranamjaya's son will be Samjjaya. His son will be Śākya. Śākya's son will be Śuddhodana. His son will be Rāhula. His son will be Prasenajit. His son will be Kṣudraka. His son will be Kuṇ̣aka. His son will be Suratha, and, finally, his son will be Sumitra. These will be the descendants of Brhadbala in the lineage of Ikșvāku. There is a verse about this branch of the family:

17 The forebears of Bṛhadbala in the Ikșvāku lineage are listed in 4.4. 
'This lineage of the Ikșvākus will finish with Sumitra. With this king, it will come to an end in the age of Kali.' 3

So ends Chapter Twenty-Two in Book Four of the glorious Viṣnu Purāna.

\section{The future descendants of Brhadratha}

\section{Parāśara:}

Now I'll name in order the future descendants of Brhadratha, who will be the kings of the Magadhas. In this lineage are mighty men with Jarāsandha as the foremost. 1 Jarāsandha's son was Sahadeva. His son will be Somāpi. His son will be Śrutavant. His son will be Ayutāyu. His son will be Niramitra. His son will be Sukșatra. His son will be Bṛhatkarman. His son will be Senajit. His son will be Śrutamjaya. His son will be Vipra. His son will be Śucināman. His son will be Kșemya. His son will be Suvrata. Suvrata's son will be Dharma. His son will be Suśrama. His son will be Dṛ̂hasena. His son will be Sumati. His son will be Subala. His son will be Sunīta. His son will be Satyajit. Satyajit's son will be Viśvajit. His son will be Ripumjaya. These kings, the descendants of Bṛhadratha, will reign for a thousand years. 2

So ends Chapter Twenty-Three in Book Four of the glorious Viṣnu Purāna.

\section{Future kings; The age of Kali}

\section{Parāsara:}

The last descendant of Brhadratha, Ripumjaya by name, will have a minister called Munika, who will kill his sovereign and then anoint his own son Pradyota as king. Pradyota's son will be called Pālaka. His son will be Višākhayūpa. His son will be Janaka, and his son will be Nandivardhana. These five Pradyota dynasts will rule the earth for one hundred and thirty-eight years. 1

Nandivardhana's son will be Śiśunāga, and his son will be Kākavarṇa. His son will be Kșemadharman. His son will be Kșatrojas. His son will be Vidhisāra, and his son will be Ajātaśatru. His son will be Darbhaka, and Darbhaka's son will be Udayana. His son will be Nandivardhana. His son will be Mahānandin. These ten kings in the lineage of Śiśunāga will rule for three hundred and sixty-two years. 2 
Mahānandin's avaricious son, Mahāpadma or Nanda, will be born to a śūdra mother. Like a second Paraśurāma, he will cause the destruction of all the ksatriyas. 3 From that time on, sundras will be the rulers of the earth. Having brought the world under one umbrella, Mahāpadma will rule unopposed. 4 He'll have eight sons, beginning with Sumālya, who will reign after him. The sons of Mahāpadma will reign for a hundred years. The brahmin Kauțilya will eradicate these nine Nandas. 5 After they have passed, the Mauryas will rule the earth. Kautitya will anoint Candragupta as king. 6 His son will be Bindusāra. His son will be Aśokavardhana. His son will be Suyaśas. His son will be Daśaratha. His son will be Samgata. His son will be Śáliśūka. His son will be Somaśarman. His son will be Śatadhanvan. His son will be called Anubṛhadratha. These ten Maurya kings will reign for one hundred and thirty-seven years.

After them the Sungas will rule the earth. 7 The general Puspamitra will kill his sovereign and usurp the kingdom. 8 His son will be Agnimitra. His son will be Sujyeștha. His son will be Vasumitra. His son will be Ārdraka. His son will be Pulindaka. His son will be Ghoșavasu. His son will be Vajramitra. His son will be Bhāgavata. 9 His son will be Devabhūti. These ten Śungas will rule the earth for one hundred and twelve years. 10

The dissolute Śnnga king Devabhūti will be killed by his own minister, a Kanva named Vasudeva, who will usurp the kingdom for himself. His son will be Bhūmitra. His son will be Nārāyaṇa. Nārāyaṇa's son will be Suśarman. These four Kāṇvāyana kings will rule for forty-five years.

The Kanva Suśarman will be violently overthrown by his own minion, Sipraka of the Andhra clan, who will then rule the earth. Next, Sipraka's brother Kṛ̣ṇa will become king. His son will be Śrīsāatakarṇi. His son will be Pūrṇotsañga. His son will be Śătakarṇi, and his son will be Lambodara. His son will be Divilaka. His son will be Meghasvāti. His son will be Pațumant, and his son will be Ariștakarman. His son will be Hāla. Hāla’s son will be Pattalaka. His son will be Pravillasena. His son will be Sundara Śātakarṇin. His son will be Cakora Śātakarṇin. His son will be Śivasvāti, and his son will be Gomatiputra. His son will be Pulimant. His son will be Śātakarṇin. His son will be Śivaśrī. His son will be Śivaskandha. His son will be Yajñaśrī. His son will be Vijaya. His son will be Candraśrī, and his son will be Pulomāvi. These thirty kings, originally servants of the Andhra clan, will rule the earth for four hundred and fifty-six years. 11 
There will be seven Ābhīra kings and ten Gardabhilas. Then there will be sixteen Śaka kings, then eight Yavanas, fourteen Tuṣāras, thirteen Muṇdas and eleven Maunas. They'll rule the earth for one thousand three hundred and ninety-nine years. 12 Following this, eleven Paura kings will rule for three hundred years. When they've been overthrown, the Kailika Yavanas will become kings, unanointed-Vindhyaśakti among them. 13 His son will be Puramjaya. His son will be Rāmacandra. His son will be Dharma. Dharma's sons will be Vangara, Kṛtanandana, Sușinandi, his brother Nandiyaśas, Śiśuka and Pravīra. They will rule for one hundred and six years and will have thirteen sons. There will be three Bāhlikas, and thirteen kings, including Pusyamitra and Pațumitra, the Mekalas and seven Andhras. There will be nine kings in Kosala, and the same number of Naișadhas. 14

In the land of the Magadhas, a king named Viśvasphațika will create new social classes and will give power to Kaivartas, Pațus, Pulindas and brahmins, having exterminated the entire order of kșatriyas. Nine Nāgas will reign in the city named Padmāvatī. The Magadha Guptas will rule in Mathurā and along the Gañgā as far as Prayāga. Devarakșita will protect Kosala, Oḍra, Pụ̣̣ra, Tâmralipta and the city by the sea. Kalingas, Māhișakas and Māhendras will rule over an earthly refuge. ${ }^{18}$ The dynasties of Manidhānakas will rule the settlements of the Naișadhas, Naimișikas and Kālatoyas. Those known as Kanakas will rule the settlements of Trairājya and Mūṣika, Saurāșțra, Avanti and Súdra. The kingdoms of Arbuda and Marubhūmi will be ruled by Vrātyas, brahmins, Abhīras, śūdras and others. The banks of the Sindhu and the realms of Dāvikorvī, Candrabhāga and Kashmir will be ruled by Vrātyas, Mlecchas and other barbarians as well as śüdras.

\section{The end of the age of Kali}

These kings will rule the earth at the same time. They'll show little mercy and be subject to intense fury, ever delighting in injustice and immorality. They'll slay women, children and cattle. They'll covet the possessions of others but will remain weak. Most will rise and fall quickly, and they'll be short-lived, having many desires but few morals. 15 Inhabitants of the various settlements will mix with them and ape their behaviour. Encouraged by the support of these kings, and with barbarians as their teachers, the populace will lead immoral lives. As a result, the daily decline and ultimate loss of wealth and virtue will cause the world to decay. 16

18 This reading as given in the Critical Edition is not very clear. A better reading is found in other editions-for example, 'The Guhas will rule over Kalinga, Māhiṣa, Mahendra and Bhauma'. 
Riches alone will confer nobility. Wealth will be the sole measure of virtue. Sex will be the only bond between couples. Womanhood will be reason enough for pleasure. Falsehood will be the basis of trade and warfare. The earth will only be valued as a source of gems and copper. The sacred thread will be the only measure of a brahmin. External trappings will be the sole indication of one's stage of life. Dishonesty will count as a profession. 17 Weakness will be the cause of dependence. Pronouncements filled with timidity will be the measure of scholarship. Wealth will be the measure of goodness. $18 \mathrm{~A}$ simple bath will count as purification. Donations will be equated with religion. Mutual consent will be the basis for a marriage. Fine clothes will confer respectability. Water from far away will substitute for a sacred ford.

In a world overwhelmed with manifold faults like these, whoever is the strongest, from any of the classes, will be king. Unable to bear the despot's excessive greed, the populace will seek refuge in hidden valleys in the mountains, subsisting on such foods as honey, vegetables, roots, berries, leaves and flowers. Clad only in the bark of trees, they'll endure heat and cold, wind and rain. No-one will live longer than twenty-three years. In this Kali age of unending decadence, humankind will meet its doom. 19

When the religion of the Vedas and scriptural tradition are in decline and the Kali age nears its end, Lord Vāsudeva-creator of the universe; master of moving and unmoving things; the beginning, end and everything between; the Absolute in the form of the highest self-will manifest an aspect of himself in this world as Kalki in the home of Viṣnuyaśas, the head brahmin in a village called Śạbala. Endowed with eight qualities and perfections, greatness and irresistible power, he will annihilate the Mlecchas and Dasyus, whose thoughts and deeds are evil. Then he will reestablish this whole world in virtue and the minds of those who live at the end of the age, waking when this night has passed, will be stainless, clear and pure. 20 Such people, who are the seeds of all humanity, even though they were begotten and matured at such a time, will bring forth progeny. Their offspring will adhere to the virtues of the Krrta age. 21 As it's said in this regard:

'When the moon, the sun, the constellation of Tisya and Jupiter all gather in one mansion, the age of Krta will begin.' 22

I've now described the kings of the past, present and future in each lineage, best of sages. 23 You should realise that, from the birth of Parikṣit to the coronation of Nanda, one thousand and fifteen years elapsed. 24 
When the first two stars of the Seven Sages (Ursa Major) are seen to rise in the heavens, and a certain lunar mansion appears at an equal distance between them at night, then the Seven Sages will remain fixed in that position for one hundred years of men. ${ }^{19} 25$

At the time of Parìkṣit, these two stars were in Maghā, best of brahmins. That marked the start of the Kali age, which endured for twelve hundred years. 26

When that aspect of Lord Viṣnu born in the family of Vasudeva returned to heaven, brahmin, the Kali age descended on the world. 27

But as long as his two feet trod this earth, the Kali age had no effect upon it. 28

When that aspect of eternal Viṣnu left the world for heaven, Yudhișthira, son of Dharma, accompanied by his younger brothers, renounced his kingdom. 29

Once Lord Kṛṣna had departed, the Pāṇdavas witnessed evil omens and anointed Parīkṣit king. 30

When the Seven Sages pass beyond Pūrvāṣāḍhā, from Nanda onwards, the influence of Kali will increase. 31

The day that Kṛsna went to heaven was the very day that Kali started. Now I'll tell you how long it will endure: 32

Three hundred thousand years, according to the reckoning of men, plus another sixty thousand, brahmin, will be the duration of the age. 33

When twelve hundred years of gods have passed, the Kṛta age will start again. 34

Brahmins, kṣatriyas, vaiśyas and suũdras, best of brahmins, all great-souled beings, pass in thousands, from age to age. 35

As there are so many names and so much repetition, I've not recounted all of them in every lineage. 36

Puru's scion King Devāpi and Maru, born in Ikșvāku's family, both possessors of great yogic power, live to this day in the village of Kalāpa. 37

Having returned to this location in the Krrta age, these two founders of kșatriya dynasties will renew the line of Manu. 38

19 This describes the precession of the equinoxes (Wilson 1961: 390, fn.82). 
The sons of Manu each rule the earth in every Kṛta, Tretā and Dvāpara age. 39

In the age of Kali, some remain on earth to reestablish lineages, just as Devāpi and Maru are doing now. 40

I've described to you the dynasties in brief, but even lifetimes by the hundred are not enough to do so fully. 41

These and other kings, blinded by delusion, grew selfish while on earth, even though their bodies perish. 42

'How may I make this mountain mine? How may my son possess the earth? How may I keep this in my family?' All these kings have met their end while harbouring thoughts like these- 43

Those who came before them, those who live beside them and others who will follow. 44

The Earth beholds these sovereigns, distracted from the path of self-control, and laughs, as if she saw spring flowers blooming in the autumn. 45

Listen to these verses that she sang, Maitreya. They were passed to Janaka, that paragon of virtue, by the sage Asita: 46

\section{The song of the Earth}

\section{The Earth:}

How could these kings be so deluded, when they're said to be so wise? Their nature is like the foam on water, yet their hearts are full of confidence. 47

Before they can control themselves, they wish to overcome their ministers, their servants and their subjects, and then they'll try to overcome their enemies. 48

'Step by step we'll vanquish all this sea-girt world!' With obsessions such as these, they fail to see that death is near at hand. 49

To have dominion over me-this whole world with oceans all around-is nothing when compared with self-control, as the reward for self-control is liberation. 50

Their forebears died but left the world behind them. Their own sires died and did not take it either. Yet these kings falsely think they own the earth and still desire to win it. 51 
Fathers fight with their own sons to conquer me, and brothers fight with brothers on account of this delusion when their hearts are gripped by selfishness. 52

'The earth is mine', 'All this belongs to me', 'This will always be my family's'. Each foolish king who had such thoughts is dead. 53

Seeing one whose heart was filled with possessiveness, and who, on leaving me, now walks the path of all who die, how could such an urge to own, which arises on my account, still find a place in their descendants' hearts? 54 At first, I want to laugh at kings whose ambassadors tell their foe, 'The earth is mine. Give up your claim!', but then I feel compassion for such fools. 55

\section{Parāśara:}

The possessiveness of those who hear these verses that the Earth once sang, Maitreya, will melt away like ice exposed to heat. 56

I've told you all about the lineage of Manu, the kings of which were aspects of Viṣnu, preserver of the universe. 57

One who's pure at heart and listens with devotion, verse by verse, to this account of Manu's line will be absolved of all misdeeds. 58

Unequalled wealth, good fortune and prosperity are yours and your senses will stay sharp once you've heard the full description of the noble dynasties of the Sun and Moon. The lineage of Raghu who've passed on-Ikșvāku, Jahnu, Māndhātṛ and Sagara, 59

As well as Yayāti, Nahuṣa and others who are no more-strong, heroic kings of boundless wealth, 60

Were all undone by mighty Time. Now all that's left are anecdotes. 61

Knowing this, and hearing these accounts, a man who is wise will never call his sons or wife, his house or fields, his goods or chattels his own. 62

Austerities performed by worthy men who hold their arms aloft for many years, and rituals carried out by mighty heroes, are all reduced by Time to tales. 63

Traversing three worlds unresisted, cleaving enemies with his discus, Prthu fell victim to the winds of Time, like cottonwood fibres in a fire. 64

Kārtavirya ruled the world; he, too, slayed enemies with his discus, butnowhe's only mentioned in some stories, giving rise to doubt about what's certain. 65 
The sovereignty of Raghu's scion, who slew ten-headed Rāvanạ, spread out in all directions, but was it not reduced to ashes the instant Yama frowned? Shame on him! 66

Having heard about Māndhātṛ, once emperor of the world, but now a figure in some story, what wise person, other than a fool, would contemplate possession? 67

Bhagīratha, Sagara, Kakutstha and Rāvaṇa, Rāma, Lakṣmaṇa, Yudhiṣthira and the others-there's no doubt they all existed, but where are they now? We just don't know. 68

The valiant kings of the present time and those of the future whom I've mentioned, plus all the others we've spoken of, will succumb like those who went before. 69

The learned man, who knows all this, entertains no sense of ownership towards himself, let alone his son, his wife, his fields or anything, excepting his own body. 70

So ends Chapter Twenty-Four in Book Four of the glorious Viṣnu Purāna. End of Book Four. 
This text is taken from The Viṣnu Puranna: Ancient Annals of the God with Lotus Eyes, translated from the Sanskrit by McComas Taylor, published 2021 by ANU Press, The Australian National University, Canberra, Australia.

doi.org/10.22459/VP.2021.04 